\section{Estudo \\ Ecidebate}

em Cestão

Planeiamento
Revista Estudo \& Debate, Lajeado, v. 26, n. 3, 2019. ISSN 1983-036X

DOI: http://dx.doi.org/10.22410/issn.1983-036X.v26i3a2019.2120

\title{
LIÇÓES DE NEGÓCIOS DE GAME OF THRONES E AS CRÔNICAS DE GELO E FOGO
}

\author{
Aline Vieira Malanovicz ${ }^{1}$
}

\begin{abstract}
Resumo: Dentre as obras literárias e obras televisivas potencialmente apoiadoras do ensino de Gestáo, destacamse As Crônicas de Gelo e Fogo e Game of Thrones. O objetivo desta pesquisa é identificar temas da área de Gestão que podem ser ensinados e debatidos com o apoio da saga literária As Crônicas de Gelo e Fogo, de George R. R. Martin, e da série de televisão Game of Thrones, do canal HBO, no ensino de gestáo. Depois de coletadas diferentes possibilidades de "liçôes" oferecidas pela saga para o ambiente de trabalho, a análise do conteúdo dos dados permitiu organizá-los em categorias. Entre as categorias identificadas, encontram-se principalmente temas ligados à Gestão de Pessoas, além de Estratégia, Informaçôes, Estudos Organizacionais, Finanças e Logística. Como um resultado adicional, o trabalho de localização de suas referências em trechos exatos dos livros e episódios permitiu fornecer um repositório de material didático de apoio aos professores e estudantes para ilustraçáo dos diversos temas tratados. Sugere-se, com base nesses achados, a efetiva realizaçáo de uma aula com uso dos materiais aqui analisados sobre As Crônicas de Gelo e Fogo e Game of Thrones, e o relato dessa experiência prática inovadora no ensino de gestáo, para maior exploraçáo e efetiva validação das possibilidades aqui propostas.
\end{abstract}

Palavras-chave: Literatura, Gestão, Tecnologias para Ensino de Gestão, Séries de Televisão.

\section{BUSINESS LESSONS FROM GAME OF THRONES AND A SONG OF ICE AND FIRE}

\begin{abstract}
Among literary books which can support management teaching, researchers highlight A Song of Ice and Fire and its TV show Game of Thrones. The objective of this research is to identify themes of the Management area that teachers and students can debate using George R.R. Martin's saga A Song of Ice and Fire and the television series Game of Thrones from channel HBO. After collecting different possibilities of "lessons" offered by the saga for the working environment, the analysis of data allowed to organize them into categories. Among the identified categories, are mainly themes related to People Management, as well as Strategy, Information, Organizational Studies, Finance and Logistics. As an additional result, the work of locating their references in exact excerpts from the books and episodes allowed to provide a repository of didactic material to support teachers and students to illustrate various topics covered. To apply these findings, we suggest the effective realization of a class using our results of A Song of Ice and Fire and Game of Thrones. We also suggest reporting this innovative practical experience in teaching management, for greater exploration and effective evidence of the possibilities proposed here.
\end{abstract}

Keyword: Literature, Management, Technologies for Teaching Management, TV Series.

1 Doutora em Administração, UFRGS, 2011. 


\section{Introdução}

Para o desenvolvimento do campo de conhecimento do Ensino de Gestão, um tema de investigação que há anos vem alcançando relevância refere-se aos desafios da inovação nos métodos (Fischer et al., 2007). Em um meio de formação educacional como o ambiente universitário, a utilização das novas tecnologias deveria ser um grande foco, tendo nos docentes universitários fortes atores no processo de apropriação dessas ferramentas (Souza e Monteiro, 2015). Entretanto, o atual modelo de universidade - que consiste em um professor com uma lousa, e alunos em cadeiras enfileiradas, no qual o professor fala e o aluno escuta, com avaliaçáo realizada por meio de provas - é muito antiquado (Vieira e Souza, 2016; Lara et al., 2017). Por exemplo, embora o auxílio da arte audiovisual no ensino seja mais comum no fundamental e médio, ainda é raro na graduação, ainda que configure uma proposta de superação das maçantes e pouco cativantes aulas expositivas (Kaneko e Herbella, 2016).

Além disso, as relaçóes entre literatura e narrativas podem agregar novidades ao processo de ensino (Alves, 2007) e oportunizar que os discentes se aproximem do campo da Gestão, explorando dimensões emocionais e lúdicas raramente abordadas nos currículos tradicionais limitados ao raciocínio lógico-analítico e formal (Pinheiro e Vieira, 2008). Também é importante que a estratégia de ensino seja concretamente situada na realidade em que vivem os estudantes, que esteja integrada ao seu cotidiano, para que sintam os efeitos imediatos do pensar que ampliam os significados da aprendizagem (Fischer et al., 2007). É possível aprender muito sobre a sociedade analisando os atuais fenômenos do entretenimento, em obras da Literatura, Cinema, Quadrinhos e Televisão (Jacoby, 2012). Percebe-se, então, que essas artes também oferecem contribuição na possibilidade de análise de temas de modo prazeroso e divertido, pois assim as liçóes são mais bem assimiladas (Veiga e Freitas, 2018).

No âmbito da utilização da televisão como ferramenta auxiliar para o ensino de alguns temas do currículo dos cursos de Gestão, séries como Game of Thrones podem servir como fonte de entretenimento e debate, tornando-se ferramentas essenciais de análise social e política (Moisi, 2015). Nesse sentido, parece que se apresenta uma oportunidade de aproveitar a popularidade dessa série televisiva (e sua série literária original) para desenvolver uma forma agradável de o público discente se aproximar de diferentes conhecimentos sobre gestão.

O objetivo desta pesquisa é identificar temas da área de Gestão que podem ser ensinados e debatidos com o apoio da saga literária As Crônicas de Gelo e Fogo, de George R.R. Martin, e da série de televisão Game of Thrones, do canal HBO. Este artigo se estrutura em seis seçôes, incluindo esta Introdução. A Seção 2 apresenta uma breve revisão sobre uso de livros, filmes e séries no ensino de gestão e detalha o corpus do objeto da pesquisa. A seção 3 descreve o método utilizado. A seção 4 apresenta uma análise dos resultados, a Seção 5 mostra a discussão desses resultados. A Seção 6 apresenta as conclusões desta pesquisa. 


\section{Referencial Conceitual}

\subsection{Livros, Filmes e Séries no Ensino de Gestão}

A Literatura pode ser um vasto campo para estudos na área de Gestão, um efetivo repositório de cases que pode ser explorado a partir de temas tratados nessa área, pois o principal elo que conecta as duas áreas seria o ser humano, como protagonista nos dois ambientes (Pinheiro e Vieira, 2008). Especialmente quando utilizados como estudos de caso para ensino, muitos textos literários são apropriados ao estudo do comportamento humano, pois uma das principais tarefas de gerentes é perscrutar coraçóes e mentes dos subordinados, superiores, clientes e fornecedores, tentando inferir e se antecipar a comportamentos (Pinheiro e Vieira, 2008). Ler obras de ficção literária é interessante para gestores de pessoas ampliarem suas habilidades de compreensão das motivaçóes das pessoas (aderindo ou resistindo a processos de mudança que permeiam suas vidas cotidianas), já que a Literatura tende a surpreender o leitor e levá-lo a considerar o lado desconhecido as forças motivacionais, que coloca impasses e enigmas que empurram para um terreno onde reinam paradoxos e novas perguntas (Ferreira, 2015). Assim, se entende que a literatura é um meio agradável e rico para estudar e pensar a gestão (Pinheiro e Vieira, 2008).

A inserção da Arte Cinematográfica também configura uma poderosa proposta de auxílio para o ensino (Kaneko e Herbella, 2016), e entre as chamadas metodologias ativas utilizadas para o ensino de Gestão está a projeção de filmes (Lara et al., 2017). Assim como os leitores, também os espectadores, quando estão focados no filme ou série, vivenciam aquela realidade (verossímil, ainda que fictícia) em todas as suas peculiaridades, experimentando se colocar no lugar do outro, e assim, se identificam com os personagens, imaginando essas outras vidas possíveis, refletindo sobre os conflitos que se apresentam (Bertoncini e Bertin, 2017). O cinema e o audiovisual podem ser aliados do desenvolvimento de uma formaçáo universitária que se atente à contemporaneidade, alcançando objetivos como a sensibilização dos alunos para uma atitude diante da realidade e a reflexão crítica acerca do universo social (Lacerda, 2007). E se destaca também o aspecto do prazer e da fruição, ao possibilitar o aprender se divertindo, especialmentepelo uso da Arte (audiovisual).

Diversas iniciativas de utilização de obras literárias e audiovisuais como instrumento de ensino e como atividades relatadas em artigos científicos publicados por docentes das áreas de Gestão podem ser enumeradas. Davel, Vergara e Djahanchah (2007) reuniram relatos de experiências a partir de manifestaçóes artísticas (cinema, literatura, teatro) aplicadas ao ensino de gestão (teorias da administração, cultura organizacional, liderança, trabalho em equipe, tomada de decisão, ética, estratégia, qualidade de vida). Ruas (2005) utilizou dramaturgia, artes cênicas, com Macbeth, de Shakespeare, para desenvolver competências gerenciais como percepção, improvisação, intuição, empatia e criatividade. Pinheiro e Vieira (2008) debateram obras como 1984 e A Revolução dos Bichos, de George Orwell (o poder e seu uso), O Senhor das Moscas, de William Golding (estilos de liderança), e Otelo e Rei Lear, de William Shakespeare (intrigas e oportunismo em questóes sucessórias) ambiente organizacional. Baêta (2007) adotou textos de Saramago na disciplina Pesquisa em Administração, e Ferreira (2007) utilizou autores como Machado de Assis, Mário de Andrade, Maria Adelaide Amaral e Hilda Hilst para tratar questóes sobre 
conflitos, negociação, subjetividade e carreira na disciplina Gestão de Pessoas. Freitas e Moscarola (2002) se apoiaram no exemplo dos detetives da ficção Hercule Poirot, Maigret e Sherlock Holmes para demonstrar métodos de pesquisa de dados para apoio à decisão dos gestores. Malanovicz (2016) destacou a descrição detalhada da gestão operacional do comércio do personagem-título e das negociaçóes de interesses entre os businessman em Ascensão e queda de César Birotteau, de Balzac. Também analisou a gestão do projeto da Catedral e as trajetórias dos quatro principais personagens e seus diferentes perfis gerenciais, com as consequências para o desenvolvimento da narrativa de Os Pilares da Terra, de Ken Follett. Ferreira (2015) incluiu Grande Sertão: Veredas e Campo Geral, de Guimarães Rosa, os contos e os grandes romances de Machado de Assis, como Dom Casmurro, Memórias Póstumas de Brás Cubas e Quincas Borba entre as obras que podem ajudar na formação de gestores, por contribuírem na formação de pessoas com visão de mundo mais ampla, diversificada e complexa.

\subsection{Corpus da pesquisa: As Crônicas de Gelo e Fogo e Game of Thrones}

A série literária As Crônicas de Gelo e Fogo, de George R.R. Martin, tem cinco livros já escritos - A Guerra dos Tronos (1996-2010), A Fúria dos Reis (1998-2011), A Tormenta de Espadas (2000-2011), O Festim dos Corvos (2005-2012) e A Dança dos Dragóes (2011-2012) - e mais dois previstos para os próximos anos para que se conclua a saga - Os Ventos do Inverno e Um Sonho de Primavera (Leya, 2016). Os livros foram adaptados para diversos formatos, como videogames, histórias em quadrinhos e uma série de TV intitulada Game of Thrones (HBO, 2011-2019), que lhe trouxe maior público e notoriedade. A série de televisão e a série de livros que lhe deu origem alcançaram notável popularidade (Moisi, 2015). Segundo a editora LeYa (2016, p.1), "é a série de fantasia mais aclamada dos últimos tempos", com profusão de tramas e personagens. Inspirado em J.R.R. Tolkien e em outros autores do gênero épico fantástico, George R.R. Martin criou uma sociedade medieval verossímil, unindo "o sentimento de admiração da fantasia ao realismo corajoso da ficção histórica” (Xavier e Rossini, 2015, p.14). O próprio título da série de TV já adquiriu um significado de algo perigoso, politicamente complexo, difícil de administrar, mostrando que Game of Thrones tornou-se uma referência cultural (Abreu e Indrusiak, 2013).

O enredo das múltiplas histórias da saga dos livros de As Crônicas de Gelo e Fogo segue três tramas principais: a crônica da disputa entre os clâs dos Sete Reinos de Westeros para tomar o Trono de Ferro; o ressurgimento de criaturas sobrenaturais chamados os Outros além da Muralha que delimita os Sete Reinos ao Norte; e a ambição dos Targaryen de voltar a Westeros para retomar o trono que fora do último rei dessa dinastia (Xavier e Rossini, 2015, p.15).

Game of Thrones: (1) Série baseada nos livros de George R.R. Martin, que conta a saga de sete nobres famílias em luta pelo controle da mítica terra de Westeros, dividida depois de uma guerra. Num cenário que lembra a Europa medieval, reis, rainhas, cavaleiros e renegados usam todos os meios em nome do poder. (2) Com a guerra chegando a Westeros, cinco reis duelam pelo poder. Em meio à disputa, alianças são forjadas e quebradas, novas lideranças surgem, e os romances 
florescem entre os personagens desta saga pelo trono. (3) A lealdade é um dos temas centrais da terceira temporada - e alguns dos personagens têm destino trágico. Lannister mantém o poder, mas está enfraquecido depois do ataque de Baratheon. No Norte, Robb Stark enfrentará momentos difíceis, enquanto um novo exército obedece às ordens de Mance Rayder. Daenerys também tem planos ousados. (4) A quarta temporada mostra muita ação e drama, na épica história de lutas e traiçôes no continente de Westeros, que ganha novos personagens e coloca antigos inimigos frente a frente. (5) A quinta temporada começa com um trono vazio, o que deixa os protagonistas de Westeros e de Essos de olho no poder. Jon luta para equilibrar as demandas da Patrulha da Noite com as necessidades de Stannis Baratheon. Cersei faz de tudo para manter sua força. Do outro lado do Mar Estreito, Arya procura um antigo amigo e Tyrion encontra uma nova causa. (6) Sobreviventes de todas as partes de Westeros e Essos se reúnem e seguem para seus destinos individuais e incertos. Novas alianças são forjadas para reforçar as chances de sobrevivência. (7) Jon é aclamado o Rei do Norte, enquanto Daenerys navega rumo a Westeros. O equilíbrio do poder está por um fio. (8) No spoiler. (HBO, 2011-2019, p.1).

\section{Metodologia}

Esta pesquisa caracteriza-se como qualitativa, exploratória e descritiva. O método de investigação adotado consiste em um levantamento bibliográfico, literário e fílmico (Baldin e Munhoz, 2011; Xavier e Rossini, 2015; Morettin et al., 2016; ECA-USP, 2019).

Quadro 1 - Caracterização do corpus bibliográfico, literário e fílmico da pesquisa

\begin{tabular}{|c|c|c|c|c|}
\hline \multirow{2}{*}{$\begin{array}{c}\text { Corpus Literário } \\
\text { Livros da Saga } \\
\text { Literária }\end{array}$} & \multirow{2}{*}{$\begin{array}{c}\text { Corpus Fílmico } \\
\text { Episódios da } \\
\text { Série de TV } \\
\end{array}$} & \multirow{2}{*}{$\begin{array}{c}\text { Corpus Bibliográfico (liçóes de } \\
\text { negócios) } \\
\begin{array}{c}\text { Ensaios, sites, artigos de jornal } \\
\text { e revista, }\end{array}\end{array}$} & \multicolumn{2}{|c|}{$\begin{array}{l}\text { Referências às séries (sem oferecer } \\
\text { necessariamente liçóes de negócios) }\end{array}$} \\
\hline & & & & $\begin{array}{l}\text { Livros, sites, cursos, } \\
\text { revistas }\end{array}$ \\
\hline $\begin{array}{l}\text { A Guerra dos Tronos } \\
\text { (aGdT) (Martin, } \\
2010) \text {, } \\
\text { A Fúria dos } \\
\text { Reis (aFdR) } \\
\text { (Martin, 2011a), } \\
\text { A Tormenta de } \\
\text { Espadas (aTdE) } \\
\text { (Martin, 2011b), } \\
\text { O Festim dos } \\
\text { Corvos (oFdC) } \\
\text { (Martin, 2012a), } \\
\text { A Dança dos } \\
\text { Dragóes (aDdD) } \\
\text { (Martin, 2012b) } \\
\text { (Martin, 2010, } \\
\text { 2011a, 2011b, } \\
\text { 2012a, 2012b) }\end{array}$ & $\begin{array}{l}\text { Game of Thrones } \\
\text { Temporada } 1 \\
\text { (10 episódios), } \\
\text { Temporada } 2 \\
\text { (10 episódios), } \\
\text { Temporada } 3 \\
\text { (10 episódios), } \\
\text { Temporada } 4 \\
\text { (10 episódios), } \\
\text { Temporada } 5 \\
\text { (10 episódios), } \\
\text { Temporada } 6 \\
\text { (10 episódios), } \\
\text { Temporada } 7 \\
\text { (7 episódios.), } \\
\text { Temporada } 8 \\
\text { (6episódios). } \\
\text { (HBO, 2019) }\end{array}$ & $\begin{array}{l}\text { Pati (2015), } \\
\text { Universia (2013), } \\
\text { Winspear (2015), } \\
\text { Lira\&Moreira (2015), } \\
\text { Taylor (2015), } \\
\text { Jacoby (2012), } \\
\text { Schulzke (2012), } \\
\text { Hahn (2012), } \\
\text { Cox (2012), } \\
\text { McCaffrey\&Dorobat (2014), } \\
\text { Tullman (2012), } \\
\text { Cerutti (2012), } \\
\text { Spector (2012), } \\
\text { Rosenberg (2012), } \\
\text { Malagón (2016), } \\
\text { Xavier\&Rossini(2015), } \\
\text { Hartinger (2012), } \\
\text { Duval (2012), } \\
\text { Vaught (2012) }\end{array}$ & $\begin{array}{l}\text { Abreu\&Indrusiak } \\
(2013), \\
\text { Jacoby (2012), } \\
\text { Maffei (2014), } \\
\text { Dias (2014), } \\
\text { Izídio et al. (2012), } \\
\text { Cerqueira (2013), } \\
\text { Xavier\&Rossini } \\
\text { (2015), } \\
\text { Couto\&Oliveira } \\
\text { (2015), } \\
\text { FCE-UFRGS } \\
\text { (2015), } \\
\text { ISAPE (2013) }\end{array}$ & $\begin{array}{l}\text { Lowder (2012), } \\
\text { Dedopulos (2015), } \\
\text { Moisi (2015), } \\
\text { Aventuras na História } \\
\text { (2011), } \\
\text { Mundo Estranho } \\
\text { (2015), } \\
\text { Rolling Stone (2014), } \\
\text { SuperInteressante } \\
\text { (2015), } \\
\text { Cogman (2013), } \\
\text { LeYa (2016), } \\
\text { GameofThronesBr/ } \\
\text { Gelo\&Fogo (2019), } \\
\text { Westeros.org (2019), } \\
\text { A Wiki of Ice and Fire } \\
\text { (2019) }\end{array}$ \\
\hline
\end{tabular}

Fonte: coleta de dados. 
Palavras-chave (string): para a delimitação do tema, foram utilizadas: Game of Thrones OR Guerra dos Tronos OR Crônicas de Gelo e Fogo. Nesta primeira busca, foram encontrados 183 itens náo-repetidos, entre artigos, notícias, tweets, redes sociais, memes, comments e posts em fóruns, blogs, wikis, fansites e outras fontes não científicas que mostram a visão do fandom sobre as obras. E foram encontrados trabalhos acadêmicos de diversas áreas: cursos e análises sobre Política e Economia (ISAPE, 2013; McCaffrey e Dorobat, 2014; FCE-UFRGS, 2015), Literatura (Abreu e Indrusiak, 2013), Filosofia (Jacoby, 2012), Moda (Maffei, 2014), Jornalismo (Dias, 2014) e Comunicação (Izídio et al., 2012; Cerqueira, 2013; Xavier e Rossini, 2015; Couto e Oliveira, 2015). Para limitar a abordagem, usaram-se strings (liçóes OR aprender OR ensinar) e (gestáo OR negócios OR administraçáo).

Filtragem: Embora tenha sido identificada uma quantidade expressiva de conteúdo na busca temática, a seleção pela abordagem eliminou diversos materiais. Entre esses, podem ser citados os produtos culturais da série, como outros livros do mesmo autor ambientados em Westeros (os contos O Cavaleiro dos Sete Reinos, de 2013, o manual de história e geografia O Mundo de Gelo e Fogo, de 2014, e a história dos reis Targaryen Fogo e Sangue, de 2018). Também eliminou reportagens de revistas, como Aventuras na História (2011), Mundo Estranho (2015), Rolling Stone (2014) e SuperInteressante (2015), e sites dedicados ao tema, como Westeros.org (2019), AWikiOfIceAndFire (2019) e GameofThronesBR/ Gelo\&Fogo (2019), livros de jogos (Dedopulos, 2015), além de, também, alguns trabalhos acadêmicos.

Coleta de Dados do Corpus Bibliográfico: depois de selecionados pela leitura do seu conteúdo, resultaram 20 materiais (cerca de $10 \%$ da primeira busca) efetivamente relacionados ao tema e abordagem da pesquisa. Cada obra eletronicamente consultada foi gravada em arquivo de planilha eletrônica, formando um banco de dados. Os trechos com lições de gestão foram tabulados junto da referência completa da obra-fonte.

Coleta de Dados do Corpus Literário: A coleta de dados do corpus literário foi realizada pela leitura dos cinco livros da saga As Crônicas de Gelo e Fogo já publicados. Optou-se pela obtenção dos livros em versão eletrônica, com o objetivo de agilizar a consulta e o destaque (marca-texto) de quaisquer trechos do texto eventualmente citados nas fontes consultadas. Os trechos demonstrativos das liçóes de gestão citados no corpus bibliográfico foram gravados no banco de dados (planilha) do corpus literário junto à referência da citação.

Coleta de Dados do Corpus Fílmico: A coleta de dados do corpus fílmico foi feita, assistindo aos 73 episódios das oito temporadas da série de televisão Game of Thrones. Optouse pela obtenção dos arquivos de legenda em português do canal de streaming (HBO, 2019), também copiados para um computador pessoal, com o objetivo de agilizar a busca por trechos de vídeo eventualmente citados no corpus bibliográfico. Trechos com liçóes foram gravados no banco de dados (planilha) do corpus fílmico, junto à referência da citação.

Procedimentos para Análise de Dados: As categorias preliminares de análise dos dados foram definidas com base nos Temas de Interesse do principal evento científico nacional da área de gestão (EnANPAD, 2019). A análise dos dados foi então realizada com base no cruzamento de referências das categorias emergentes das liçóes de Game of Thrones. 
Entre as limitaçôes metodológicas do método de pesquisa, pode-se citar a abrangência apenas nacional dos textos consultados, justificada pela aproximação da aplicabilidade das liçóes ao contexto brasileiro. Também deve ser reconhecido algum grau de subjetividade na atribuição de categorias aos dados coletados, pois é possível que outros pesquisadores descubram classificaçóes novas (e/ou mais detalhadas) com base nesses mesmos dados.

\section{Resultados e Análises}

Esta seção apresenta os resultados da coleta e análise de dados, identificando as liçóes de gestão destacadas nas obras consultadas, e atribuindo uma categoria temática a cada lição. Optou-se por apresentar os resultados da análise na forma de grandes quadros divididos pelos temas das liçóes. Discrimina-se o assunto resultante da categorização, as liçóes propostas no corpus bibliográfico, e as referências (ou trechos) identificadas do corpus literário ou fílmico. As referências a páginas dos livros ou ao tempo dos episódios são dadas em imagens.

Quadro 2 - Liçóes de Liderança

\begin{tabular}{|c|c|c|}
\hline $\begin{array}{c}\text { Tema/ } \\
\text { Assunto }\end{array}$ & $\begin{array}{c}\text { Liçóes - Pati } \\
(2015)\end{array}$ & Referências ao corpus literário ou fílmico \\
\hline Vigilância & $\begin{array}{l}\text { Estar vigilante } \\
\text { quanto a novos } \\
\text { maus tempos }\end{array}$ & $\begin{array}{l}\text { O inverno está chegando. } \\
\text { (Martin, 2010, aGdT, p. } 24,25,50,66,169,177,223,239,405,429,687 \text {; } \\
\text { Martin, 2011a, aFdR, p. } 662,950,1290,2396 ; \\
\text { Martin, 2011b, aTdE, p. } 136,289,864 ; \\
\text { Martin, 2012a, aFdC, p. } 332,346,457,608,668,669 ; \\
\text { Martin, 2012b, aDdD, p. } 54,88,95,150,184,193,266,290,325,330,333,343 \text {, } \\
395,434,437,439,543,545,715,740,882,891,919)\end{array}$ \\
\hline Decisóes & $\begin{array}{l}\text { Ter noção do } \\
\text { impacto das } \\
\text { decisóes difíceis } \\
\text { que se toma }\end{array}$ & $\begin{array}{l}\text { O homem que decreta a sentença deve brandir a espada. } \\
\text { (Martin, 2010, aGdT, p.17, 385; Martin, 2011a, aFdR, p.1259, 2107) } \\
\text { (HBO, Ep 1.1 Winter is coming, 11:43-11:45 e 44:30-44:37, } \\
\text { Ep 1.3 Lord Snow, 06:37-06:39 e 14:44-14:53 e 49:30-49:33, } \\
\text { Ep 2.3 What Is Dead May Never Die, 13:58-14:02, } \\
\text { Ep 3.3 Walk of Punishment, 47:00-47:04, } \\
\text { Ep 3.4 And Now His Watch Is Ended, 00:57-01:00 e 29:47-29:49, } \\
\text { Ep 4.10 The Children, 07:10-07:13, } \\
\text { Ep 5.3 High Sparrow, 25:32-25:34, } \\
\text { Ep 5.4 The Sons of the Harpy, 05:56-05:59, } \\
\text { Ep 5.5 Kill the Boy, 10:39-10:42 e 40:26-40:28, } \\
\text { Ep 5.7 The Gift, 18:11-18:13) }\end{array}$ \\
\hline Adimplência & $\begin{array}{l}\text { Cumprir suas } \\
\text { promessas e assim } \\
\text { inspirar respeito e } \\
\text { admiração }\end{array}$ & 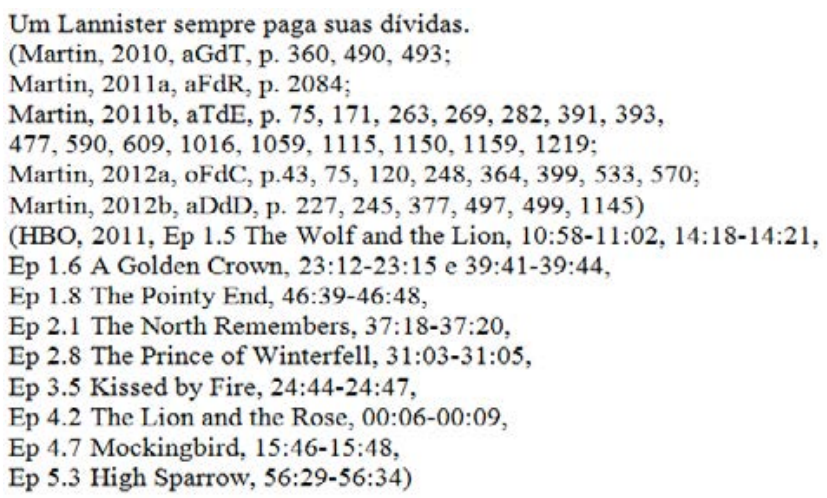 \\
\hline
\end{tabular}




\begin{tabular}{|c|c|c|}
\hline $\begin{array}{c}\text { Tema/ } \\
\text { Assunto }\end{array}$ & $\begin{array}{c}\text { Liçóes - Pati } \\
(2015)\end{array}$ & Referências ao corpus literário ou fílmico \\
\hline Autoridade & $\begin{array}{l}\text { Descolar a } \\
\text { verdadeira } \\
\text { liderança e } \\
\text { a posição de } \\
\text { autoridade } \\
\end{array}$ & $\begin{array}{l}\text { Qualquer homem que tenha de dizer "sou o rei" não é rei de verdade. } \\
\text { (Martin, 2011b, a TdE, p.748) } \\
\text { (HBO, 2013, Ep 3.10 Mhysa, 07:05-(09:04-(09:08-09:13)-10:50)-13:58) }\end{array}$ \\
\hline Desafios & $\begin{array}{l}\text { Fortalecer a } \\
\text { capacidade de } \\
\text { liderança na } \\
\text { dificuldade dos } \\
\text { desafios }\end{array}$ & $\begin{array}{l}\text { O caos não é uma cova, é uma escada. } \\
\text { (HBO, 2012, Ep } 2.6 \text { The Old Gods and The New, 16:25-(17:06-17:27)-18:50) } \\
\text { (HBO, 2013, Ep 3.6 The Climb, 46:16-(48:00-48:25)-49:20)) }\end{array}$ \\
\hline Dedicação & $\begin{array}{l}\text { Trabalhar, } \\
\text { influenciar e ter } \\
\text { credibilidade para } \\
\text { poder liderar }\end{array}$ & $\begin{array}{l}\text { Qualquer tolo com sorte pode nascer no poder, mas conquistá-lo para si dá trabalho. } \\
\text { (HBO, 2015, Ep 5.1 The Wars to Come, 32:27-(33:40-33:50)-35:37) }\end{array}$ \\
\hline Treinamento & $\begin{array}{l}\text { Treinar e } \\
\text { aprimorar-se para } \\
\text { sustentar o sucesso }\end{array}$ & $\begin{array}{l}\text { A mente precisa de livros assim como a espada precisa da pedra de afiar. } \\
\text { (HBO, 2011, Ep } 1.2 \text { The Kingsroad, 25:30-(26:25-27:40)-28:40) } \\
\text { - Por que você lê tanto? } \\
\text { Tyrion ergueu os olhos ao ouvir aquela voz. Jon Snow estava a alguns pés de } \\
\text { distância, olhando-o com curiosidade. (..) } \\
\text { - Tenho um entendimento realista das minhas forças e fraquezas. A mente é a minha } \\
\text { ama. Meu imão tem a sua espada, o Rei Robert, o seu martelo de guerra, e eu } \\
\text { tenho a mente... e uma mente necessita de livros da mesma forma que uma espada } \\
\text { necessita de uma pedra de amolar se quisermos que se mantenha afiada - Tyrion deu } \\
\text { uma palmada na capa de couro do livro. - É por isso que leio tanto, Jon Snow. } \\
\text { (Martin, 2010, aGdT, p.125) } \\
\text { (HBO, 2011, Ep 1.2 The Kingsroad, } 25: 30-(26: 25-27: 40)-28: 40)\end{array}$ \\
\hline
\end{tabular}

Fonte: coleta de dados.

\section{Quadro 3 - Liçóes de Carreira}

\begin{tabular}{|c|l|l|}
\hline \multicolumn{1}{|c|}{$\begin{array}{c}\text { Tema/ } \\
\text { Assunto }\end{array}$} & $\begin{array}{l}\text { Liçóes - Universia } \\
(\mathbf{2 0 1 3 )}\end{array}$ & \multicolumn{1}{|c|}{ Referências ao corpus literário ou fílmico } \\
\hline Concorrência & $\begin{array}{l}\text { Através de } \\
\text { campanhas de } \\
\text { marketing e guerras } \\
\text { de negócios e use } \\
\text { esse tempo para } \\
\text { construir a sua } \\
\text { própria fortaleza, } \\
\text { atraindo os seus } \\
\text { clientes }\end{array}$ & $\begin{array}{l}\text { Deixar os competidores se destruírem, como diz Tyrion } \\
\text { (HBO, 2012, Ep 2.1 "The North Remembers", 08:30-(09:01-09:14)-10:09) }\end{array}$ \\
\hline
\end{tabular}




\begin{tabular}{|c|c|c|}
\hline $\begin{array}{l}\text { Tema/ } \\
\text { Assunto }\end{array}$ & $\begin{array}{c}\text { Liçóes - Universia } \\
(2013)\end{array}$ & Referências ao corpus literário ou fílmico \\
\hline Lealdade & $\begin{array}{l}\text { Oferecer liberdade } \\
\text { gerando lealdade, } \\
\text { como faz Daenerys } \\
\text { - é melhor criar } \\
\text { um ambiente de } \\
\text { opçóes, onde os seus } \\
\text { colegas sejam leais } \\
\text { por opção e não } \\
\text { imposição }\end{array}$ & $\begin{array}{l}\text { - Muito bem-disse Dany, - Mercenário ou escravo, poupe todos aqueles que me } \\
\text { juraremlealdade. Se um número suficiente dos Segundos Filhos se juntar a mim, } \\
\text { mantenhla a companhia intacta. } \\
\text { Na manhã do terceiro dia, os portðes da cidade abriram-se e uma fileira de escravos } \\
\text { começou a sair, Dany montou a prata para ir ao encontro deles, Ao passarem, a } \\
\text { pequena Missandei foi-lhes dizendo que deviama liberdade a Daenerys Nascida na } \\
\text { Tormenta, a Não Qucimada, Rainha dos Setc Rcinos de Westeros c Mãe de Dragõcs. } \\
\text { - Mhysa! - gritou-lhe um homem de pele mulata, } \\
\text { Ele trazia uma criança ao ombro, uma menininha, e ela gritou a mesma palavra em } \\
\text { sua vozinha fina: } \\
\text { - Mhysa! Mhysa! } \\
\text { Dany olhou para Missandei. } \\
\text { - O que estão eles gritando? } \\
\text { - E ghiscari, a antiga língua pura. Quer dizer Mãe. } \\
\text { (Martin, 2011b, aTdE, p.570) } \\
\text { (HBO, 2013, Ep 3.10 Mhysa, 58:41-(01:00:08-01:00:39)-01:01:50) }\end{array}$ \\
\hline Lealdade & $\begin{array}{l}\text { Oferecer gentileza } \\
\text { gerando lealdade }\end{array}$ & $\begin{array}{l}\text { A Casa Stark de Winterfell é conhecida por governar o norte de } \\
\text { Westeros com a ajuda de seus súditos sempre leais }\end{array}$ \\
\hline Networking & $\begin{array}{l}\text { Cultivar a } \\
\text { influência, } \\
\text { como Lorde } \\
\text { Varys- construa } \\
\text { um networking } \\
\text { promissor que } \\
\text { pode gerar muitas } \\
\text { oportunidades } \\
\end{array}$ & $\begin{array}{l}\text { - Lorde Varys sabe tudo - disse Petyr com um soriso malicioso. - Nada acontece } \\
\text { nesta cidade sem que Varys fique sabendo. Por vezes, ele sabe das coisas antes de } \\
\text { elas acontecerem. Tem informantes por todo o lado. Chama-os de seus passarinhos. } \\
\text { - Saberá Varys sobre... } \\
\text { - Lorde Varys sabe tudo... } \\
\text { (Martin, 2010, aGdT, p.179-180) } \\
\text { (HBO, 2015, Ep 5.10 Mother's Mercy, 35:20-(36:03-36:20)-36:55) }\end{array}$ \\
\hline União & $\begin{array}{l}\text { Fortalecer a união } \\
\text { gerando poder, } \\
\text { como mostra o } \\
\text { rei Robert - uma } \\
\text { equipe unida é } \\
\text { mais poderosa do } \\
\text { que indivíduos que } \\
\text { trabalham por si sós }\end{array}$ & (HBO, 2011, Ep 1.5 The Wolf and the Lion, 42:33-(43:55-44:14)-44:28) \\
\hline Planejamento & $\begin{array}{l}\text { Planejar as } \\
\text { estratégias - } \\
\text { essencial para evitar } \\
\text { desastres e conflitos } \\
\text { desnecessários, e } \\
\text { pode levar você } \\
\text { longe }\end{array}$ & $\begin{array}{l}\text { (HBO, 2012, Ep } 2.5 \text { The Ghost of Harrenhal, 10:35-(11:52-12:08)-12:55) } \\
\text { (HBO, 2012, Ep } 2.8 \text { The Prince of Winterfell, 20:10-(21:24-21:53)-23:52) }\end{array}$ \\
\hline
\end{tabular}




\begin{tabular}{|c|c|c|}
\hline $\begin{array}{l}\text { Tema/ } \\
\text { Assunto }\end{array}$ & $\begin{array}{c}\text { Liçóes - Universia } \\
(2013)\end{array}$ & Referências ao corpus literário ou fílmico \\
\hline Confiança & $\begin{array}{l}\text { Saber em quem } \\
\text { confiar - aprenda } \\
\text { a diferença entre } \\
\text { aliados e inimigos } \\
\text { e saiba quem são } \\
\text { aqueles que vão } \\
\text { levar a sua carreira } \\
\text { um passo adiante }\end{array}$ & $\begin{array}{l}\text { Ned o seguiu, desconfiado, perguntando a si mesmo se aquele dia chegaria ao fim. } \\
\text { Não tinha nenhum gosto por aquelas intrigas, mas começava a compreender que } \\
\text { para um homem como Mindinho elas eram naturais como o ar que respirava. } \\
\text { (Martin, 2010, aGdT, p.208) } \\
\text { Mindinho soriu. } \\
\text { - Prometi a Cat que o ajudaria na sua investigação, e foi o que fiz. } \\
\text { Ned foi apanhado de surpresa. Com ou sem promessas, não era capaz de confiar em } \\
\text { Mindinho, que lhe parecia muitissimo mais inteligente do que deveria. } \\
\text { (Martin, 2010, aGdT, p.279) } \\
\text { - Sinto-me grato por sua ajuda. Talvez tivesse sido errado de minha parte } \\
\text { desconfiar de você. } \\
\text { Mindinho afagou sua pequena barba pontiaguda. } \\
\text { - E lento para aprender, Senhor Eddard. Desconfiar de mim foi a coisa mais sensata } \\
\text { que fez desde que desceu de seu cavalo. } \\
\text { (Martin, 2010, aGdT, p. } 281 \text { ) } \\
\text { (HBO, 2011, Ep } 1.7 \text { You win or you die, } 53: 20-(57: 53-58: 29) \text { ) }\end{array}$ \\
\hline
\end{tabular}

Fonte: coleta de dados.

\section{Quadro 4 - Mais Liçóes para Carreira}

\begin{tabular}{|c|c|c|}
\hline Tema/Assunto & Liçóes - Winspear (2015) & Referênciasao corpus literário ou fílmico \\
\hline Mentoring & \begin{tabular}{|l|} 
Encontrar um mentor é \\
uma das melhores formas \\
de crescer profissionalmente \\
\end{tabular} & $\begin{array}{l}\text { Arya com Syrio e Jaqen, Bran com Jojen e o Corvo, e Sansa } \\
\text { com Cersei e Mindinho }\end{array}$ \\
\hline Informação & $\begin{array}{l}\text { Estar bem informado é um } \\
\text { diferencial }\end{array}$ & \begin{tabular}{|l|} 
Varys sabe quais informaçóes são relevantes para quais \\
pessoas, para o mercado, e o que dizem os concorrentes
\end{tabular} \\
\hline Adaptação & Adaptar-se para sobreviver & $\begin{array}{l}\text { Arya desenvolve habilidades, aprende a fazer alianças, ativa } \\
\text { a capacidade de adaptação, de mudar de estratégia de forma } \\
\text { ágil }\end{array}$ \\
\hline Oportunidades & Reconhecer oportunidades & $\begin{array}{l}\text { Bronn se arriscou a defender Tyrion porque viu a } \\
\text { possibilidade de ascensáo ao trabalhar para a família real }\end{array}$ \\
\hline Inspiração & $\begin{array}{l}\text { Inspirar seus seguidores e } \\
\text { entender as necessidades da } \\
\text { sua equipe }\end{array}$ & $\begin{array}{l}\text { Daenerys construiu um império em menos de três } \\
\text { temporadas, entendeu a cultura dos Dothraki, liderou-os, } \\
\text { consolidou sua influência nesta cultura, inspirou-os a seguir } \\
\text { seus objetivos e expandiu seu império, e formou legióes de } \\
\text { seguidores libertos }\end{array}$ \\
\hline Networking & $\begin{array}{l}\text { Preservar e desenvolver sua } \\
\text { rede de contatos }\end{array}$ & $\begin{array}{l}\text { Varys com seus passarinhos. Mindinho consegue enxergar } \\
\text { o panorama político do continente como um todo, e desse } \\
\text { modo pode influenciar decisóes de diferentes líderes em } \\
\text { vários lugares }\end{array}$ \\
\hline Criatividade & $\begin{array}{l}\text { Usar limitaçóes e aumentar } \\
\text { a capacidade criativa }\end{array}$ & $\begin{array}{l}\text { "Cripple, Bastards and Broken Things" (aleijados, bastardos e } \\
\text { quebrados), por exemplo, Bran, Jon e Tyrion }\end{array}$ \\
\hline Ambição & $\begin{array}{l}\text { Cuidar o excesso de } \\
\text { ambição }\end{array}$ & Theon caiu em suas próprias ilusóes de grandeza \\
\hline Perseverança & Perseverar & $\begin{array}{l}\text { Todos os Stark, Daenerys e Jon, enfrentaram posiçóes de } \\
\text { desprestígio, mas com esforços diários, mostraram aptidóes, } \\
\text { aprenderam muito e conquistaram respeito e reconhecimento } \\
\text { de seus próximos, consolidando sua reputação a cada vitória }\end{array}$ \\
\hline Arrogância & Não ser arrogante & Tragédias de Joffrey são resultado de suas decisóes arrogantes \\
\hline
\end{tabular}

Fonte: coleta de dados. 


\begin{tabular}{|c|c|c|}
\hline $\begin{array}{l}\text { Tema/ } \\
\text { Assunto }\end{array}$ & $\begin{array}{l}\text { Liçóes - Lira } \\
\text { e Moreira } \\
(2015) \\
\end{array}$ & Referências ao corpus literário ou fílmico \\
\hline Subestimar & $\begin{array}{l}\text { Não } \\
\text { subestimar os } \\
\text { mais fracos }\end{array}$ & Crianças Stark \\
\hline Argumentação & $\begin{array}{l}\text { Exercer a } \\
\text { habilidade de } \\
\text { argumentação }\end{array}$ & $\begin{array}{l}\text { Davos Seaworth solicita financiamento ao Banco de Braavos: no primeiro } \\
\text { momento, o Banco rejeita o pedido, mas Davos apresenta, com confiança, } \\
\text { argumentos a favor de Stannis e motivos pelos quais o Banco deve ajudá-lo } \\
\text { Śó restou um líder confiável em Westeros e ele é Stannis. Ele tem o direito de } \\
\text { nascença, tem a experiência como um comandante de batalha e não fica só falando } \\
\text { em pagar as pessoas, ele de fato o faz. E os banqueiros cedem. } \\
\text { (HBO, 2014, Ep 4.6 The Laws of Gods and Men, 01:53-(05:32-(07:30-07:48))) }\end{array}$ \\
\hline Ouvir & $\begin{array}{l}\text { Ouvir as } \\
\text { demandas }\end{array}$ & $\begin{array}{l}\text { A khaleesi Daenerys conquista diversas cidades, tenta melhorar a vida dos } \\
\text { povos, não deixa de ouvir os problemas de seus súditos, e procura fazer o } \\
\text { possível para atender aos seus pedidos }\end{array}$ \\
\hline Acomodação & $\begin{array}{l}\text { Não se } \\
\text { acomodar }\end{array}$ & $\begin{array}{l}\text { Vários personagens queridos cometeram erros fatais, como ficar confortáveis } \\
\text { nas posiçóes em que estavam }\end{array}$ \\
\hline Esperança & $\begin{array}{l}\text { Acreditar no } \\
\text { impossível }\end{array}$ & $\begin{array}{l}\text { Bran Stark tinha todos os motivos para desistir: ficou paraplégico, perdeu } \\
\text { vários familiares e teve que fugir de Winterfell para sobreviver. Com ajuda } \\
\text { dos amigos, conseguiu fugir, descobriu ser um warg, capaz de entrar na } \\
\text { mente de animais e controlá-los, e encontrou Lorde Corvo de Três Olhos } \\
\text { - Estou aqui - disse Bran - só que estou quebrado. Tu vais... tu vais consertar-me? } \\
\text { Consertar-me as pernas, quero eu dizer. } \\
\text { - Não - disse o pálido lorde. - Isso está para lá dos meus poderes. } \\
\text { Os olhos de Bran encheram-se de lágrimas. Percorremos um caminho tão longo. A } \\
\text { sala ecoou com o som do rio negro. } \\
\text { - Nunca mais voltarás a andar, Bran - prometeram os pálidos lábios - mas irás voar. } \\
\text { (Martin, 2012b, aDdD, p. 588) } \\
\text { (HBO, 2014, Ep 4.10 The Children, 31:53-(38:50-(40:09)-40:24)) }\end{array}$ \\
\hline
\end{tabular}

Fonte: coleta de dados.

Quadro 6 - Lições de Finanças

\begin{tabular}{|c|c|c|}
\hline Tema/Assunto & $\begin{array}{c}\text { Liçóes - Taylor } \\
(2015)\end{array}$ & Referências ao corpus literário ou fílmico \\
\hline Imparcialidade & $\begin{array}{l}\text { Tomar decisóes } \\
\text { imparciais }\end{array}$ & $\begin{array}{l}\text { Impulsividade pode gerar um Red Wedding } \\
\text { - Mãe - disse -, tenho a grande honra de lhe apresentar a Senhora Jeyne Westerling, } \\
\text { filha mais velha de Lorde Gawen, e minha... ah... e a senhora minha esposa. } \\
\text { O primeiro pensamento que passou pela cabeça de Catelyn foi: Não, não pode ser, } \\
\text { você é só uma criança. O segundo foi: E, além disso, está prometido a outra. O } \\
\text { terceiro foi: Pela misericórdia da Mãe, Robb, o que você fez? (...) } \\
\text { - E você - disse ela suavemente - perdeu os Frey. } \\
\text { O estremecimento dele disse tudo. (...) Como pôde fazer isso, Robb? Como pôde ser } \\
\text { tão imprudente, tão estúpido? Como pôde ser tão... tão, tão... jovem. Mas censuras } \\
\text { de nada serviriam ali. Tudo que disse foi: } \\
\text { - Conte-me como isso aconteceu. } \\
\text { - Conquistei o castelo dela, e ela conquistou meu coração. - Robb sorriu. (..) } \\
\text { - Insultou gravemente a Casa Frey, Robb. } \\
\text { (Martin, 2011b, aTdE, p.193-195) } \\
\text { (HBO, 2013, Ep 3.7 The Bear and the Maiden Fair, 05:40-(06:21-06:32)-06:40) }\end{array}$ \\
\hline
\end{tabular}




\begin{tabular}{|c|c|c|}
\hline Tema/Assunto & $\begin{array}{c}\text { Liçóes - Taylor } \\
(2015)\end{array}$ & Referências ao corpus literário ou fílmico \\
\hline Negociação & $\begin{array}{l}\text { Usar os recursos } \\
\text { disponíveis }\end{array}$ & 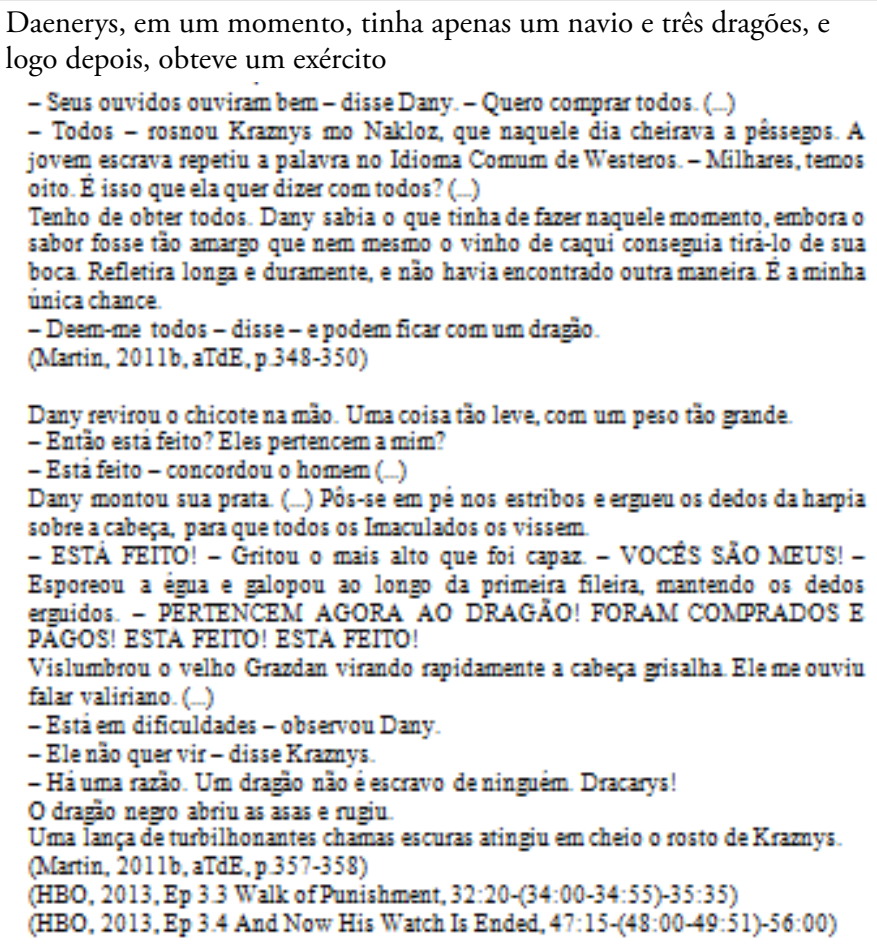 \\
\hline Patrimônio & $\begin{array}{l}\text { Considerar a } \\
\text { importância do } \\
\text { patrimônio }\end{array}$ & A influência dos Tyrell vem das suas terras \\
\hline Dívidas & $\begin{array}{l}\text { Considerar } \\
\text { dívidas como } \\
\text { um problema }\end{array}$ & 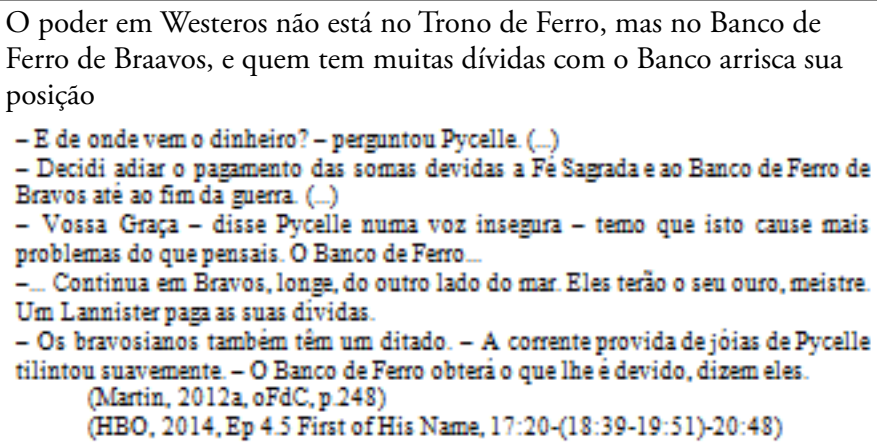 \\
\hline
\end{tabular}

Fonte: coleta de dados. 


\begin{tabular}{|c|c|c|}
\hline Tema/Assunto & $\begin{array}{c}\text { Liçóes - Jacoby (2012) (vários } \\
\text { capítulos) }\end{array}$ & Referências ao corpus literário/fílmico \\
\hline $\begin{array}{c}\text { Moralidade, } \\
\text { honra, ética do } \\
\text { poder, o papel } \\
\text { de um tirano } \\
\text { e os motivos } \\
\text { que tornam } \\
\text { um conflito } \\
\text { (armado) justo } \\
\text { ou injusto }\end{array}$ & $\begin{array}{l}\text { Os conflitos e a complexidade } \\
\text { moral de pessoas e sociedades, } \\
\text { assim como a relevância da luta } \\
\text { dos personagens com os dilemas } \\
\text { filosóficos de suas escolhas, não } \\
\text { parecem distantes das escolhas } \\
\text { enfrentadas no mundo real } \\
\text { diariamente. }\end{array}$ & $\begin{array}{l}\text { Algumas lições são tão conflituosas quanto os } \\
\text { personagens da narrativa, por exemplo: } \\
{ }^{*} \text { Quem dita a sentença deve manejar a espada } \\
{ }^{*} \text { O amor é o veneno da honra, a morte do dever } \\
\text { *Ao jogar o jogo dos tronos, ou ganha ou morre }\end{array}$ \\
\hline \multirow{4}{*}{$\begin{array}{l}\text { Idealismo } \\
\text { Hahn (2012) }\end{array}$} & \multirow{3}{*}{$\begin{array}{l}\text { Quem tem sorte, sagacidade e sabe } \\
\text { usar a força sobrevive se conseguir } \\
\text { se manter constantemente alerta, } \\
\text { enquanto outros se tornam vítimas } \\
\text { do conflito. Todos são vulneráveis } \\
\text { e não há segurança, só a constante } \\
\text { luta pelo poder, que, por ser } \\
\text { efêmero, até os poderosos podem } \\
\text { ser destruídos quando se tornam } \\
\text { preguiçosos ou são desafiados por } \\
\text { alguém mais competente. }\end{array}$} & $\begin{array}{l}\text { Quem quiser fazer profissão de bondade, é natural que } \\
\text { se arruíne entre tantos que são maus }\end{array}$ \\
\hline & & (Nicolau Maquiavel apud Hahn, 2012, p.89) \\
\hline & & 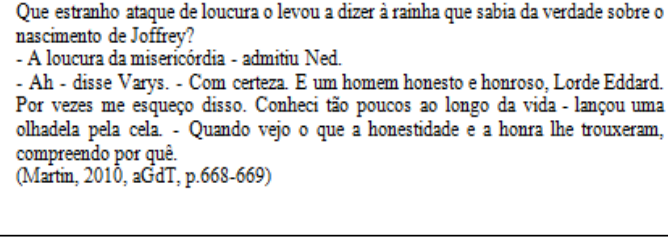 \\
\hline & $\begin{array}{l}\text { Saber quando ser bom e quando } \\
\text { náo ser bom }\end{array}$ & $\begin{array}{l}\text { Para não acabar como Ned Stark, que morreu por } \\
\text { causa de sua honra }\end{array}$ \\
\hline \multirow{3}{*}{$\begin{array}{l}\text { Liçóes de } \\
\text { Maquiavel }\end{array}$} & \multirow{2}{*}{$\begin{array}{l}\text { Desenvolver a habilidade de tomar } \\
\text { e manter o poder, fazer mudanças } \\
\text { contínuas com base nas condiçōes } \\
\text { e com base nisso criar o próprio } \\
\text { caminho para o poder }\end{array}$} & (Ações de Robb Stark e ações de Mindinho) \\
\hline & & $\begin{array}{l}\text { Itália renascentista de Maquiavel era semelhante } \\
\text { ao Mundo de Gelo e Fogo, sempre ameaçados por } \\
\text { guerras e manobras políticas }\end{array}$ \\
\hline & Sempre usar uma máscara & $\begin{array}{l}\text { É o que faz o mais maquiavélico dos personagens da } \\
\text { saga, Mindinho (mas também como Arya e Jon) }\end{array}$ \\
\hline $\begin{array}{l}\text { Schulzke } \\
(2012)\end{array}$ & $\begin{array}{l}\text { Ter o apoio dos nobres (poderosos, } \\
\text { porém traiçoeiros) ou das pessoas } \\
\text { comuns (mais fáceis de agradar); } \\
\text { procurar ser amado e temido }\end{array}$ & $\begin{array}{l}\text { É necessário ser respeitado e um pouco temido, porém } \\
\text { náo odiado como Joffrey, um péssimo modelo de } \\
\text { comportamento para um rei }\end{array}$ \\
\hline $\operatorname{Cox}(2012)$ & $\begin{array}{l}\text { Cercar-se de conselheiros sábios e } \\
\text { altamente respeitados. }\end{array}$ & $\begin{array}{l}\text { Meistres sáo a ordem de sábios, curadores, chefes de } \\
\text { correios e cientistas de Westeros. Seu conhecimento } \\
\text { é prático e teórico. Obtêm aros de suas correntes } \\
\text { ao estudar sobre diferentes áreas, como política, } \\
\text { engenharia e até medicina. }\end{array}$ \\
\hline \multirow[t]{2}{*}{$\begin{array}{l}\text { Relativismo } \\
\text { cultural }\end{array}$} & $\begin{array}{l}\text { Não supor que as próprias práticas } \\
\text { morais têm base num padrão } \\
\text { racional e universal }\end{array}$ & \multirow{2}{*}{$\begin{array}{l}\text { No contexto do encontro de Daenerys com os } \\
\text { Dothraki, há açóes que são suportadas pelo relativismo } \\
\text { moral, mas não todas, pois há açôes que, não importa } \\
\text { em qual cultura se esteja, são erradas. }\end{array}$} \\
\hline & $\begin{array}{l}\text { Manter a mente aberta quanto às } \\
\text { práticas de outras culturas, mesmo } \\
\text { tendo dificuldade em aceitá-las }\end{array}$ & \\
\hline
\end{tabular}




\begin{tabular}{|c|l|l|}
\hline Tema/Assunto & $\begin{array}{c}\text { Liçóes - Jacoby (2012) (vários } \\
\text { capítulos) }\end{array}$ & \multicolumn{1}{|c|}{ Referências ao corpus literário/fílmico } \\
\hline \multirow{5}{*}{ Estratégias } & $\begin{array}{l}\text { Qualquer situaçáa em que se } \\
\text { usam estratégias para chegar } \\
\text { a um fim desejado pode ser } \\
\text { considerada um jogo - Lidar } \\
\text { com cada jogador como uma (2012) } \\
\text { pessoa em situaçáo única (usando } \\
\text { empatia para com ele), nấo só } \\
\text { como um agente sempre racional, } \\
\text { pois o discernimento melhora a } \\
\text { capacidade de prever, entender e } \\
\text { estimular açóes alheias, facilitando } \\
\text { os próprios fins }\end{array}$ & $\begin{array}{l}\text { Mantenha sempre seus inimigos } \\
\text { confusos. Se nunca estiverem seguros } \\
\text { de quem é ou do que quer, não podem } \\
\text { saber o que é provável que faça em } \\
\text { seguida. As vezes, a melhor maneira } \\
\text { de confundi-los é fazer coisas que não } \\
\text { têm nenhum propósito, ou até que } \\
\text { parecem prejudicar você. Lembre-se } \\
\text { disso, Sansa, quando começar a jogar. } \\
\text { (Martin, 2011b, aTdE, p. 933-934) }\end{array}$ \\
\hline
\end{tabular}

Fonte: coleta de dados.

\section{Quadro 8 - Liçôes sobre Questóes de Gênero}

\begin{tabular}{|c|c|c|}
\hline Tema/Assunto & Liçóes & Referências ao corpus literário ou fílmico \\
\hline $\begin{array}{c}\text { Poder } \\
\text { Spector (2012) }\end{array}$ & $\begin{array}{l}\text { O uso e abuso do } \\
\text { poder corrompe e } \\
\text { oprime }\end{array}$ & $\begin{array}{l}\text { Corrupçáo do poder e opressão tanto para homens quanto para } \\
\text { mulheres, especialmente os que desviam das normas de gênero: Brienne, } \\
\text { Varys, Samwell, Asha }\end{array}$ \\
\hline $\begin{array}{c}\text { Feminismo } \\
\text { Spector (2012) }\end{array}$ & $\begin{array}{l}\text { As mulheres } \\
\text { precisam mais de } \\
\text { voz própria, pois } \\
\text { seus caminhos } \\
\text { para chegar } \\
\text { ao poder são } \\
\text { restritos }\end{array}$ & $\begin{array}{l}\text { As inquietaçóes dos personagens femininos são fundamentais para } \\
\text { ilustrar a desconexão entre as ilusões da sociedade sobre si mesma e } \\
\text { a angustiante realidade (Sansa, a boa moça; Arya, a rebelde; Asha, } \\
\text { a capitá; Cersei, a rainha má; Daenerys, a nova mulher; Brienne, a } \\
\text { isolada; todas estáo em jornadas para criar um lugar no mundo para } \\
\text { si mesmas e obter o controle sobre a própria vida, enfrentando os } \\
\text { obstáculos colocados em seus caminhos por uma sociedade opressiva) }\end{array}$ \\
\hline $\begin{array}{l}\text { Rosenberg } \\
(2012)\end{array}$ & $\begin{array}{l}\text { As diferentes } \\
\text { atitudes em } \\
\text { relaçáo às } \\
\text { mulheres } \\
\text { indicam uma } \\
\text { medida do grau } \\
\text { de civilizaçâa dos } \\
\text { povos }\end{array}$ & $\begin{array}{l}\text { Em Westeros, a habilidade para matar é sinal de masculinidade e até } \\
\text { honra, e a má conduta sexual significa monstruosidade: no Povo Livre, } \\
\text { Craster é um estuprador incestuoso; na Patrulha da Noite, há diversos } \\
\text { estupradores; nas Ilhas de Ferro, as Esposas de Sal sáo escravizadas } \\
\text { sexualmente; Daenerys tenta impor a proibiçáo do estupro aos } \\
\text { Dothraki; na corte de Porto Real, Joffrey é um sádico que abusa de } \\
\text { Sansa; Ramsay, nascido de estupro, é outro sádico que caça mulheres } \\
\text { com cáes; a Montanha é um monstro que estuprou e matou a princesa } \\
\text { Elia }\end{array}$ \\
\hline $\begin{array}{l}\text { Opressão } \\
\text { feminina }\end{array}$ & $\begin{array}{l}\text { As mulheres } \\
\text { oprimidas por } \\
\text { serem mulheres } \\
\text { querem deixar de } \\
\text { ser assim }\end{array}$ & $\begin{array}{l}\text { A série mostra um mundo medieval sexista e violento, onde mulheres } \\
\text { sofrem mais opressão que homens. Entretanto, a série castiga mulheres } \\
\text { que tentam se libertar, e mostra que fracassam por causa de seus erros } \\
\text { ditos femininos - Mulheres empoderadas como Daenerys (Mhysa, } \\
\text { Máe de Dragóes) e Cersei (Rainha, Mãe do Rei, Rainha-Mãe) têm } \\
\text { na maternidade sua importância. E a sororidade (“sisterhood”), que } \\
\text { une Olenna\&Sansa, Catelyn\&Brienne, Shae e Ros para ajudar Sansa, } \\
\text { resulta em punição (Ros) }\end{array}$ \\
\hline Cerutti (2012) & $\begin{array}{l}\text { Cada grande } \\
\text { mudança política } \\
\text { tem sempre } \\
\text { a força de } \\
\text { uma mulher a } \\
\text { impulsionando } \\
\end{array}$ & $\begin{array}{l}\text { Sob a perspectiva política feminina, as mulheres de Westeros são sua } \\
\text { peça principal, as coadjuvantes que acabam por decidir o verdadeiro } \\
\text { destino de cada homem em toda a saga - a astúcia de Cersei, o poder de } \\
\text { Daenerys, a coragem de Arya, a traição de Sansa, a ousadia de Brienne, } \\
\text { a magia de Melisandre, a atitude de Catelyn (que prendeu Tyrion, p.ex.) }\end{array}$ \\
\hline
\end{tabular}




\begin{tabular}{|c|c|c|}
\hline $\begin{array}{l}\text { Tyrion Lannister soltou um risinho } \\
\text { abafado. Foi nesse momento que } \\
\text { Catelyn soube que o tinha na mão. } \\
\text { - Este homem chegou como convidado } \\
\text { a minha casa e ali conspirou para } \\
\text { matar meu filho, um rapaz de sete anos } \\
\text { - proclamou para toda a sala, } \\
\text { apontando. Sor Rodrik deslocou-se } \\
\text { para o seu lado, de espada na mão. - } \\
\text { Em nome do Rei Robert e dos bons } \\
\text { senhores que servem, solicito-lhes que } \\
\text { o capturem e me ajudem a devolvê-lo a } \\
\text { Winterfell, onde esperará a justiça do } \\
\text { rei. } \\
\text { Não saberia dizer o que lhe deu maior } \\
\text { satisfação: se o som de uma dúzia de } \\
\text { espadas a serem empunhadas como } \\
\text { uma só, ou se a expressão no rosto de } \\
\text { Tyrion Lannister. } \\
\text { (Martin, 2010, aGoT, p.321-322) } \\
\text { (HBO, 2011, Ep 1.4 Cripples, Bastards } \\
\text { and Broken Things, 51:27-(53:50)- } \\
54: 30 \text { ) }\end{array}$ & $\begin{array}{l}\text { Sou a única criança com quem os } \\
\text { deuses permitiram que ficasse. A } \\
\text { anormal, que não serve para ser um } \\
\text { filho ou uma filha - tudo jorrou } \\
\text { então de Brienne, como sangue } \\
\text { negro de uma ferida; as traições e } \\
\text { os noivados, Ronnet Vermelho e } \\
\text { sua rosa, Lorde Renly dançando } \\
\text { com ela, a aposta sobre sua } \\
\text { virgindade, as lágrimas amargas } \\
\text { que derramara na noite em que seu } \\
\text { rei se casou com Margaery Tyrell, o } \\
\text { corpo a corpo em Ponteamarga, o } \\
\text { manto arcoíris de que tanto se } \\
\text { orgulhara, a sombra no pavilhão do } \\
\text { rei, Renly morrendo em seus } \\
\text { braços, Correrrio e a Senhora } \\
\text { Catelyn, a viagem ao longo do } \\
\text { Tridente, o duelo com Jaime nos } \\
\text { bosques. } \\
\text { (Martin, 2012a, oFdC, p. 474) } \\
\text { (HBO, 2015, Ep 5.3 High Sparrow, } \\
\text { 18:28-(20:47-23:14)-23:54) }\end{array}$ & $\begin{array}{l}\text { - Elia de Dorne - todos } \\
\text { ouviram Sor Gregor dizer, } \\
\text { quando os dois ficaram } \\
\text { suficientemente próximos para } \\
\text { se beijar. Sua voz profunda } \\
\text { retumbava dentro do elmo. - } \\
\text { Matei a criazinha chorona } \\
\text { dela. - Lançou a mão livre } \\
\text { contra o rosto sem proteção de } \\
\text { Oberyn, enfiando dedos de aço } \\
\text { em seus olhos. - E entäo a } \\
\text { estuprei. -Clegane esmagou o } \\
\text { punho na boca do dornês, } \\
\text { transformando seus dentes em } \\
\text { lascas. - E depois esmaguei a } \\
\text { porra da cabeça dela. Assim. - } \\
\text { Quando puxou para trás o } \\
\text { enorme punho, o sangue em } \\
\text { sua manopla pareceu fumegar } \\
\text { no ar frio da alvorada. Ouviu- } \\
\text { se um crunch nauseante. } \\
\text { (Martin, 2011b, aTdE, p.1125) }\end{array}$ \\
\hline
\end{tabular}

Fonte: coleta de dados.

Quadro 9 - Lições Econômicas

\begin{tabular}{|c|c|c|}
\hline Tema/Assunto & Liçóes - McCaffrey e Dorobat (2014) & Referências ao corpus literário ou fílmico \\
\hline Desperdícios & $\begin{array}{l}\text { Dívidas servem apenas como um meio } \\
\text { (custoso e) temporário (e não para } \\
\text { cobrir desperdícios monumentais) }\end{array}$ & $\begin{array}{l}\text { Finanças estatais - O Mestre da Moeda cria } \\
\text { tributos, mas são temporários, pois metade } \\
\text { dos senhores do reino náo poderia tolerar uma } \\
\text { tributação tirânica e fugiria num piscar de olhos } \\
\text { para o usurpador mais próximo caso isso lhes } \\
\text { salvasse uma moeda de cobre. }\end{array}$ \\
\hline
\end{tabular}

Fonte: coleta de dados.

Quadro 10 - Liçóes de Relaçóes Interpessoais

\begin{tabular}{|c|c|c|}
\hline $\begin{array}{c}\text { Tema/ } \\
\text { Assunto }\end{array}$ & Liçóes & Referências ao corpus literário ou fílmico \\
\hline $\begin{array}{c}\text { Perspectivas } \\
\text { Xavier e } \\
\text { Rossini (2015) }\end{array}$ & $\begin{array}{l}\text { Gerentes que lidam } \\
\text { com pessoas devem } \\
\text { sempre considerar } \\
\text { as perspectivas dos } \\
\text { diferentes envolvidos } \\
\text { em um conflito ou uma } \\
\text { negociação, para tomar } \\
\text { decisôes imparciais }\end{array}$ & $\begin{array}{l}\text { Jaime Lannister, nas primeiras temporadas da série televisiva, é um } \\
\text { personagem verossímil e coeso, de quem primeiro se obtém um } \\
\text { conhecimento fragmentário e superficial, a partir de personagens } \\
\text { que têm seus Pontos de Vista, mas que, do terceiro livro da saga } \\
\text { em diante, abre-se com Ponto de Vista próprio. } \\
\text { Martin diz: "Nos livros, parte de minha intenção com os Lannister } \\
\text { é vê-los primeiro do lado de fora. Parecem infames, mas, quando } \\
\text { se penetra a mente deles e a história é contada de seu ponto de } \\
\text { vista, tem-se nova perspectiva. Talvez ainda sejam infames, porém, } \\
\text { você começa a entendê-los um pouco mais e a saber por que fazem } \\
\text { o que fazem." (Cogman, 2013, p.72). }\end{array}$ \\
\hline
\end{tabular}




\begin{tabular}{|c|c|c|}
\hline $\begin{array}{c}\text { Tema/ } \\
\text { Assunto }\end{array}$ & Liçóes & Referências ao corpus literário ou fílmico \\
\hline $\begin{array}{l}\text { Estereótipos } \\
\text { Hartinger } \\
\text { (2012) }\end{array}$ & $\begin{array}{l}\text { A experiência de } \\
\text { ser um desajustado } \\
\text { social (tratado como } \\
\text { objeto de escárnio, } \\
\text { ridicularizaçáo ou } \\
\text { pena, ser ignorado ou } \\
\text { estereotipado) parece } \\
\text { tornar a pessoa mais } \\
\text { sensível ao sofrimento } \\
\text { dos outros }\end{array}$ & $\begin{array}{l}\text { Sete personagens são desajustados sociais, que violam seu gênero } \\
\text { ou as normas sociais ou de aparência física: Tyrion, Arya, Jon, } \\
\text { Daenerys, Bran, Samwell, Brienne, Varys, Renly e Loras } \\
\text { - Não me chame Lorde Snow. } \\
\text { O anão ergueu uma sobrancelha. } \\
\text { - Preferiria ser tratado por Duende? Se deixá-los perceber que suas palavras o } \\
\text { magoam, nunca se verá livre da troça. Se lhe quiserem atribuir um nome, aceite-o, } \\
\text { faça-o seu. Assim, não poderão voltar a magoá-lo com ele. } \\
\text { (Martin, 2010, aGdT, p. 195) } \\
\text { (HBO, 2011, Ep 1.1 Winter is coming, 40:49-(42:40-43:30)) }\end{array}$ \\
\hline $\begin{array}{l}\begin{array}{l}\text { Ambiguidade } \\
\text { moral }\end{array} \\
\text { Vaught (2012) }\end{array}$ & $\begin{array}{l}\text { Ninguém é santo, e } \\
\text { dificilmente há um } \\
\text { adulto sem pecado, em } \\
\text { menor ou maior grau }\end{array}$ & $\begin{array}{l}\text { Robb (perjuro), Catelyn (rancorosa) e Joffrey (cruel) náo } \\
\text { encontram a redençáo - Davos (justo) e Sansa (aprendiz) que } \\
\text { parecem estar nessa jornada exaustiva de redenção }\end{array}$ \\
\hline
\end{tabular}

Fonte: coleta de dados.

Um resumo dos achados da análise e categorização de dados é mostrado em forma tabulada (Quadro 11). Os trechos individuais mais citados foram "O inverno está chegando", "Quem decreta a sentença deve brandir a espada", e "Um Lannister sempre paga suas dívidas". Isso não surpreende, pois essas são as frases mais emblemáticas da saga. Pode-se observar a identificação de diferentes temas da área de gestáo, principalmente de Gestão de Pessoas (GPR), mas também de Estratégia (ESO), Informaçōes (ADI), e Estudos Organizacionais (EOR), além de Finanças (FIN), Logística (GOL) e Inovação (GCT). Como um resultado adicional, o extenso trabalho de localização de suas referências em trechos exatos dos livros e episódios permitiu fornecer um repositório de material didático de apoio aos professores e estudantes para ilustração dos diversos temas tratados. Os temas mais recorrentes foram Liderança e Desenvolvimento Gerencial, Competências, Gestão de Carreiras, e Formulaçáo e Mudança das Estratégias, pois as principais liçóes indicam como tornar-se uma liderança e gerenciar estrategicamente. Destacam-se também Estratégia e Conhecimento, Estratégia e Cooperação, Conhecimento e Aprendizagem, e Trabalho, Gestão e Subjetividade, relativos ao modo de lidar com os conflitos no ambiente organizacional. Percebe-se, assim, que diferentes temas da área de gestão são abordados na dinâmica da saga. 


\section{Quadro 11 - Categorização das Liçóes Identificadas}

\begin{tabular}{|c|c|c|}
\hline Licōes Gerenciais Identificadas & Trechos do Corpus & Categorizaçăo dos Temas \\
\hline $\begin{array}{l}\text { Manter vigiláncia para tempos dificeis } \\
\text { Prestar atençào aos stnats de perigo } \\
\text { Manter-se constantemente alerta } \\
\text { Saber quo todos astâo vulnorávots }\end{array}$ & $\begin{array}{l}\text { O twemo } \\
\text { está cheganda }\end{array}$ & ESO Formulaçào e Mudança das Estratégias \\
\hline 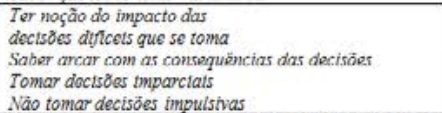 & $\begin{array}{l}\text { Quem decreta a sentença } \\
\text { dhe brandir a espada. } \\
\text { O conor é o veneno da honna, a morte do dever. }\end{array}$ & $\begin{array}{l}\text { ADI Processo Decisúrio } \\
\text { GPR Lideraņ̧a e Desenvolvimento Gerencial }\end{array}$ \\
\hline 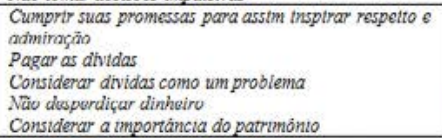 & $\begin{array}{l}\text { Uim Lannister sempre para suas dividas. } \\
\text { O Banco de Ferro obterá o que the é devidio. }\end{array}$ & FIN Finanças Corporativas \\
\hline 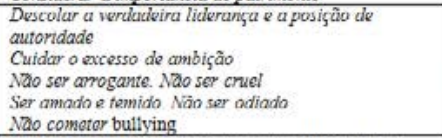 & $\begin{array}{l}\text { O homem que procisa } \\
\text { dizer "Eu sou o rei" } \\
\text { não é un verdadeiro rei. }\end{array}$ & $\begin{array}{l}\text { GPR Liderança e Desenvolvimento Gerencial } \\
\text { GPR Prazer e Sofrimento no Trabalho }\end{array}$ \\
\hline $\begin{array}{l}\text { Trabalhar duro, influenciar e ter credibilidade para } \\
\text { poder liderar } \\
\text { Desemoher a habilidade de tomar o poder e de } \\
\text { mantor o poder } \\
\text { Planejar estrategias } \\
\text { Pursoverur mos mo na adversidade }\end{array}$ & $\begin{array}{l}\text { Quando vocé joga o jogo dos tronos, } \\
\text { ou vocé ganha, ou vocé morre. } \\
\text { Qualquer tolo com sorte pode nascer en meio ao } \\
\text { poder. mas conquistá lo dá trabalho. }\end{array}$ & $\begin{array}{l}\text { GPR Gestão de Carreiras } \\
\text { GPR Liderança e Desenvolvimento Gerencial } \\
\text { GPR Competências }\end{array}$ \\
\hline $\begin{array}{l}\text { Treinar e aprimorar-se } \\
\text { para sustontar o sucosso } \\
\text { Ter conhecimento teorico para } \\
\text { aplicar o conhocimento prático }\end{array}$ & $\begin{array}{l}\text { A mente precisa de lnvos } \\
\text { assim como a espada } \\
\text { precisa da pedra de afiar }\end{array}$ & $\begin{array}{l}\text { GPR Conhecimento e Aprendizagem } \\
\text { GPR Competências } \\
\text { GPR Liderança e Desenvolvimento Gerencial }\end{array}$ \\
\hline $\begin{array}{l}\text { Cultrvar a mfluéncia } \\
\text { Estur bem informado } \\
\text { Preservar e desernohiver a rede de contatos }\end{array}$ & Larde Varys sabe tudo & $\begin{array}{l}\text { ESO Estratégia e Conhecimento } \\
\text { AIJI Gicstão da Informação }\end{array}$ \\
\hline $\begin{array}{l}\text { Encontrur um mentor } \\
\text { Aprender rapido } \\
\text { Ter scagacidade } \\
\text { Reconhecer opontunidades } \\
\text { Portalecer a capacidade de liderança na dificuldate } \\
\text { dos desaflos }\end{array}$ & $\begin{array}{l}\text { E a mantpular vocé aprondou com o molhor. } \\
\text { O cuus não ó uma cova, é uma cscutla. }\end{array}$ & $\begin{array}{l}\text { GPR Conhecimento e Aprendizagem } \\
\text { GPR Gicstăo de Carresras } \\
\text { ESO Estratégia e Conhecimento }\end{array}$ \\
\hline Dexaar os competidores se destruirem & $\begin{array}{l}\text { Os nossas inimigos se odeiam quese tanto quanto } \\
\text { odelam a nós. } \\
\text { Mantenha sempre sous inimigas confiusas }\end{array}$ & ESO Vantagem Competitiva \\
\hline $\begin{array}{l}\text { Promover liberdado que gera loaldade } \\
\text { Promover gentileza que gera lealdade } \\
\text { Promover igualdadle que gera lealdade } \\
\text { Inspirar seus segutdore }\end{array}$ & $\begin{array}{l}\text { - Daenerys: Mhinsa (Mäe) } \\
\text { - Robb: Jovom Lobo } \\
\text { - Mance: Rei do Povo Livre } \\
\text { - Stunnis. "fanflurrũo" } \\
\text { - Balon: rebeliäo fracassada } \\
\text { - Joffrey. "um munstro" }\end{array}$ & $\begin{array}{l}\text { GPR Modelos e Praticas de Gestảo de Pcssoas } \\
\text { GPR Liderança e Desenvolvimento Gerencial }\end{array}$ \\
\hline 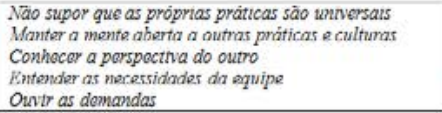 & $\begin{array}{l}\text { Vocé nĩo me dá ordens, khalevsi } \\
\text { Meu nome é.Jaime, nảo Regicida }\end{array}$ & $\begin{array}{l}\text { ESO Negócios Internacionais } \\
\text { ESO Formulaçăo e Mudança das Estratégias } \\
\text { EOR Culturas e Identıdades em Organızaçōes }\end{array}$ \\
\hline $\begin{array}{l}\text { Fortalecer a untâo gerando poder } \\
\text { Obler o apoio dos nobres e plebeus } \\
\text { Unur os cläs } \\
\text { Exercer sua habilidade de argumentaçâo } \\
\text { Saber usar a força }\end{array}$ & 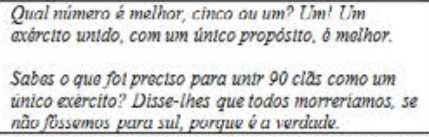 & $\begin{array}{l}\text { ESO Estratégia e Couper açào } \\
\text { GPR Liderança e Desenvolvimento Gerencial } \\
\text { GOL Redes de Operações }\end{array}$ \\
\hline $\begin{array}{l}\text { Jogar usando estrategios para alcmegar as fins } \\
\text { desefados } \\
\text { Lidar com cada jogador usando empatia } \\
\text { Sempre usur uma máscara } \\
\text { Saber em quen confiar } \\
\text { Saber quando ser bom e quando nũo ser }\end{array}$ & 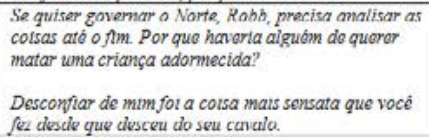 & $\begin{array}{l}\text { ESO Estratégia e Cooperação } \\
\text { GPR Liderança e Desenvolvimento Gerencial } \\
\text { GPR Trabalho, Gestão e Subjetıvidade }\end{array}$ \\
\hline $\begin{array}{l}\text { Usar limuttaçoes para aumentar a capactiade criativa } \\
\text { Nho subestimar as que parecem fraras } \\
\text { Sonstbiltzar-so com o sofrtmonto alhoto } \\
\text { Deservolver empatia } \\
\text { Julgar a ctviltidado das possoas polas attudes om } \\
\text { relaçäo as mulheres }\end{array}$ & $\begin{array}{l}\text { Se quiserem atributr a vocé um apelido. } \\
\text { tome-o como seu, } \\
\text { assim nào podevào voltar a magoá lo com ele }\end{array}$ & $\begin{array}{l}\text { EOR Géncro c Diversidade } \\
\text { GPR Trabaltho e Diversidade } \\
\text { GPR Trabalho, Gestão e Subjetividade }\end{array}$ \\
\hline $\begin{array}{l}\text { Adaptar-so para sobrovtvor } \\
\text { Adaptar-se com facilidade a mudangers } \\
\text { Fazer mudanças continuas com baso nas } \\
\text { circunstâncias } \\
\text { Usar os recursos disponiveis } \\
\text { Ser pragmático }\end{array}$ & $\begin{array}{l}\text { Doom-me todos os Imaculados, } \\
\text { e podem ficar com um dragäo. }\end{array}$ & $\begin{array}{l}\text { GPR Competèncias } \\
\text { GPR Gestão de Carreiras } \\
\text { ESO Formulaçăo e Mudaņ̧̧ das Estratégias }\end{array}$ \\
\hline $\begin{array}{l}\text { Acroditar no tmpossivol } \\
\text { Năo se acomodar } \\
\text { Ter sorle }\end{array}$ & Bran, vocé iná voar. & $\begin{array}{l}\text { GCT Inovação e Empreendedorismo } \\
\text { GPR Estrategia e Empreendedorismo }\end{array}$ \\
\hline
\end{tabular}

Fonte: coleta de dados. 


\section{Discussão}

Percebe-se, pela análise dos resultados da pesquisa, que diferentes liçóes de negócios podem ser identificadas na série literária As Crônicas de Gelo e Fogo e na série televisiva Game of Thrones. As ocorrências de comentários, análises e debates sobre variados temas de gestão associados às séries (identificados na pesquisa em fontes tão diversas como artigos de revistas e jornais, posts, blogs e websites e outros produtos culturais e jornalísticos) mostram a atualidade e inserção do tema na cultura pop. Essa presença cativa mais o interesse dos alunos do que as tradicionais aulas expositivas (Kaneko e Herbella, 2016). Por outro lado, as ocorrências de análises em ensaios filosóficos, políticos, culturais, científicos e econômicos, e dissertaçóes de mestrado, mostram o interesse acadêmico, a abrangência e a profundidade dos debates propiciados pela análise das obras em contextos de diferentes áreas relativas à Gestão.

Nesse sentido, para a exploração da possibilidade de aprender se divertindo com uso da Literatura e do Audiovisual, vale ressaltar que o professor passa a ter o papel de despertar a reflexão e estimular o potencial de desenvolvimento dos alunos, como se faz em metodologias ativas de ensino, diferentemente das aulas expositivas convencionais (Lara et al., 2017). Para Finanças, por exemplo, pode ser proposta a análise do comportamento da família Lannister ou do Banco de Ferro de Braavos; para Liderança, a comparação entre atitudes de Daenerys e Jon Snow (e Joffrey!); para Estratégia, a comparação entre o lema da família Stark e as ambiçóes do Lorde Baelish; para Gestão da Informação, a investigação dos métodos de Varys.

Uma ressalva operacional que deve ser mencionada é que, para trabalhar utilizando os livros e vídeos, é necessário que os alunos leiam as obras e assistam aos episódios da série (ou pelo menos leiam alguns capítulos e assistam a alguns episódios selecionados), para que possam entender o contexto sociopolítico e o comportamento dos personagens. O tempo disponível para os estudantes lerem e assistirem fora do período de aula pode talvez limitar a aplicação da proposta a disciplinas. Entretanto, também se visualiza a aplicação da estratégia a diferentes situaçóes de ensino, como grupos de estudo ou cursos de extensão com aulas semanais (com tempo suficiente para a apropriação do conteúdo dos capítulos e episódios), e cursos à distância com debates em fóruns síncronos ou assíncronos, por exemplo.

Assim, percebe-se o potencial da Literatura e do Audiovisual como campos de estudos contemporâneos na área de Gestão e como poderosos aliados no ensino (Kaneko e Herbella, 2016; Lara et al., 2017). O completo foco da atenção do leitor/espectador na situação do case apresentado na trama permite a ele vivenciar essa experiência como sendo parte dela, e assim refletir com crítica e sensibilidade, para assim atuar na realidade social e organizacional (Lacerda, 2007; Bertoncini e Bertin, 2017). A possível identificação do leitor/espectador com os personagens das tramas e seus comportamentos proporciona a ampliação das habilidades de compreensão de motivaçóes, impasses e conflitos, próprios das tarefas dos gerentes (Pinheiro e Vieira, 2008; Ferreira, 2015). Assim, entende-se que a utilização da Literatura e do Audiovisual, aqui investigados nas séries As Crônicas de Gelo e Fogo e Game of Thrones, são meios prazerosos, agradáveis, divertidos e ricos de se aprimorar o processo de ensino-aprendizagem de diferentes aspectos da área de Gestão. 
Vale citar que a capacidade de uma série de televisão mostrar para a sociedade seus anseios e ansiedades refletidos a torna popular (Moisi, 2015) e ressalta a importância de que a estratégia de ensino esteja situada concretamente na realidade dos alunos, integrada no seu cotidiano. Isso vale para desenvolver um modo agradável de aproximar ao público de estudantes diferentes conhecimentos de Gestão. Neste caso, no mundo corporativo e no contexto do ensino de Gestão para a formação profissional, as liçóes encontradas na série literária e na série televisiva podem representar uma possibilidade de oferecer aos estudantes essa forma de reflexão.

\section{Conclusão}

Nesta pesquisa, foram identificados temas da área de Gestão que podem ser ensinados e debatidos com o apoio da saga literária As Crônicas de Gelo e Fogo, de George R.R. Martin, e da série de televisão Game of Thrones, do canal HBO, no ensino de gestão. Assim, pode-se considerar que foi alcançado o objetivo deste trabalho. Dado o foco desta pesquisa, a classificação se limitou a temas pertinentes ao ensino de gestão, mas percebem-se diversas dimensôes de análise das obras associadas a outras áreas do conhecimento.

Esta pesquisa destacou o potencial da Literatura e do material Audiovisual, exemplificados pela série literária e pela série televisiva, como auxiliares no processo de ensino-aprendizagem ativo, contemporâneo e desassociado das aulas expositivas na área de Gestão. A aproximação - ou até plena inserção - do leitor/espectador na realidade do case representado na obra ficcional apresenta grande potencial, em termos de auxílio na formação acadêmica, para mobilizar o interesse e a reflexão crítica para a tomada de decisão gerencial.

Outros exemplos de séries literárias e audiovisuais (séries de livros e filmes) com potencial para uso no ensino de Gestão são: Os Pilares da Terra, O Senhor dos Anéis e Jogos Vorazes. E séries de televisão como The Office, Downton Abbey e House of Cards também podem servir como fonte de entretenimento e debate, tornando-se ferramentas essenciais de análise social e política (Moisi, 2015). Estas são sugestóes de trabalhos futuros, assim como a realização de uma atividade didática com uso dos materiais aqui analisados sobre As Crônicas de Gelo e Fogo e Game of Thrones, para efetiva comprovação das possibilidades discutidas.

Nesta pesquisa, a principal contribuição científica à área de Gestão refere-se ao aspecto educacional desse tema. $\mathrm{O}$ trabalho indica um meio simples de apresentar para os alunos a discussão sobre macro temas da Gestão de uma forma diferente da convencional. Trata de uma temática relevante na medida em que se propóe a investigar formas de ensino-aprendizagem que se aproximam à realidade dos alunos.A pesquisa aborda um tema peculiar na área de Gestão, buscando articular Literatura e obra audiovisual ao ensino, o que indica originalidade, criatividade e elaboração de uma estratégia inovadora para o ensino. Acredita-se que a pesquisa seja de interesse para docentes de Gestão, pois novas estratégias de ensino, que aumentem o engajamento dos alunos, valem ser consideradas. 


\section{Referências}

ABREU, L.C.; INDRUSIAK, E.B. Game of Thrones: o impacto cultural de um processo adaptativo em desenvolvimento. Translatio: revista do Núcleo de Estudos de Tradução. Porto Alegre/RS. n.6 (2013), p.62-76.

ALVES, Luiz Roberto. Por um saber administrativo que compartilhe a história da cultura brasileira. In: EnANPAD, 31, 2007, Rio de Janeiro: Anais... Rio de Janeiro: ANPAD, 2007.

AVENTURAS NA HISTÓRIA. Trono manchado de sangue: os hábitos, as guerras e as Quadros reais que serviram de referência para o best-seller As Crônicas de Gelo e Fogo. São Paulo, n.98, p.29-35, set.2011.

BAÊTA, A.M.C. Saramago no ensino e aprendizagem de metodologia de pesquisa. In: DAVEL, E.; VERGARA, S. C.; DJAHANCHAH, P. G. (org.). Administração com Arte. São Paulo: Atlas, 2007. cap.10, p.101-108.

BALDIN, N.; MUNHOZ, E.M.B. Snowball (Bola de Neve): uma técnica metodológica para pesquisa em Educação Ambiental Comunitária. In: Congresso Nacional de Educação - Educere, 10., Curitiba, 7-10nov.2011, Anais... Curitiba: PUC-PR, 2011.

BERTONCINI, C.; BERTIN, F.D. Ensino Jurídico e Cinema. Simpósio Regional Direito e Cinema em Debate, 3. Direito e Cinema Contemporâneoem Debate. Jacarezinho, PR: UENP\&PROJURIS, 2017.

CERQUEIRA, R.C.B. Práticas de assistir televisão: um olhar sobre a série Game of Thrones na HBO. In: Congresso Brasileiro de Ciências da Comunicação - InterCom, 37. Manaus, Anais... Manaus: UFAM, 2013.

CERUTTI, J. Sangue e Fogo: Westeros pelo olhar feminino em $A$ Song of Ice and Fire. Literatura. n.45, 2012. http://literatura.uol.com.br/literatura/Quadros-linguagem/45/ sangue-e-fogo-westeros-pelo-olhar-feminino-em-a-song-273457-1.asp

COGMAN, B. Por dentro da série da HBO Game of Thrones. São Paulo: LeYa, 2013.

COUTO, P.R.D.; OLIVEIRA, L.A. Quando se joga o Jogo dos Tronos, você vence ou morre: representaçóes sociais e disputas pelo poder em Game of Thrones. Mediaçáo; v.17, n.20, 2015.pp.45-60; p.2179-9571; p.1676-2827. http://www.fumec.br/revistas/ mediacao/article/view/2922/1719

COX, E. Magia, ciência e metafísica em A Guerra dos Tronos. In: JACOBY, H. (org.) A Guerra dos Tronos e a Filosofia. Rio de Janeiro: BestSeller, 2012. p.143-154.

DAVEL, E.; VERGARA, S.C.; DJAHANCHAH, P.G. (org.). Administraçáo com Arte: experiências vividas de ensino-aprendizagem. São Paulo: Atlas, 2007. 
DEDOPULOS, T. Desafios e Enigmas dos Tronos: inspirados no romance e na premiada série Game of Thrones. Rio de Janeiro: Ediouro, 2015. 208p.

DIAS, N.S. Remix dos Cavaleiros: recirculação jornalística na forma de imagens remixadas. Artigo de Pós-Graduação, Especialização em Jornalismo e Convergência de Mídias, Feevale, Novo Hamburgo-RS, 2014. 18p.

DUVAL, S. As coisas que faço por amor. In: JACOBY, H. (org.) A Guerra dos Tronos e a Filosofia. Rio de Janeiro: BestSeller, 2012. p.259-272.

ECA-USP. História e Audiovisual: Circularidades e Formas de Comunicação.

ColóquioInternacional de Cinema e História. 5., UFPR, Curitiba, PR, 3-6 dez. 2019. Recuperado em 20 junho, 2019, de http://historiaeaudiovisual.weebly.com/ivcoloacutequio.html

ENANPAD.Encontro Nacional da ANPAD. Santos/SP,2019. http://www.anpad.org.br/ Acesso em 1 jul.2019.

FCE-UFRGS -Faculdade de Ciências Econômicas UFRGS. Game of Thrones e a Filosofia. Curso de Extensão. Mediação: J.M.Q. Martins. 2-6mar.15. http://www.ufrgs. $\mathrm{br} /$ fce/curso-game-of-thrones-e-a-filosofia-comeca-hoje/

FERREIRA, R. Ficção literária no ensino e aprendizagem de gestão de pessoas. In: DAVEL, E.; VERGARA, S.C.; DJAHANCHAH, P.G. (org.). Administraçáo com Arte. São Paulo: Atlas, 2007. p.109-117.

FERREIRA, R.G. Literatura e Gestão. In: Estadão: Blogs: Gestão,Política\&Sociedade. 17abr.2015 http://politica.estadao.com.br/blogs/gestao-politica-e-sociedade/literatura-egestao

FISCHER, T.; DAVEL, E.; VERGARA, S.; GHADIRI, S.D. Razão e Sensibilidade no ensino de administração: literatura como recurso estético. Rio de Janeiro, Revista de Administração Pública, v.41, n.5, p.935-956, 2007.

FREITAS, H.; MOSCAROLA, J. Da Observação à Decisão: métodos de pesquisa e de análise quantitativa e qualitativa de dados. RAE-eletrônica, v.1, n.1, jan-jun.2002, pp.1-30. http://www.rae.com.br/eletronica/index.cfm?FuseAction=Artigo \&ID=1159\&Secao $=$ INFORMAÇÃO $\&$ Volume $=1 \&$ Numero $=1 \&$ Ano $=2002$

GAMEOFTHRONESBR. Tudo sobre o universo de George R.R. Martin. 2019. http:// www.geloefogo.com.br

HAHN, D. A morte de lorde Stark: os perigos do idealismo. In: JACOBY, H. (org.) A Guerra dos Tronos e a Filosofia. Rio de Janeiro: BestSeller, 2012. p.89-99.

HARTINGER, B. Um tipo diferente de outro: o papel de aberrações e párias em Game of Thrones. In: LOWDER, J. (org.) Além da Muralha. São Paulo: LeYa, 2012. p.119-129. 
HBO. Game of Thrones. criado e produzido por D.B.Weiss e David Benioff. Estados Unidos, HBO, 2011-2019. 73 episódios (43800min./73h.) http://www.hbo.com/gameof-thrones.

ISAPE - Instituto Sul-Americano de Política e Estratégia. Curso de Extensão:Game of Thrones e a Filosofia. 06/nov.-18/dez.2013. https://isape.wordpress.com/2013/10/22/ curso-de-extensao-game-of-thrones-e-a-filosofia/

IZÍDIO, A.R.R.; CAVALCANTI, G.K.M.; VILAÇA, G.; LUCIAN, R. Entretenimento digital na indústria cultural: uma análise de conteúdo das estratégias usadas na divulgação do seriado Game of Thrones. Simpósio Nacional ABCIber, Entretenimento digital:

Anais.... Novo Hamburgo/RS: Feevale, 2012, 6. 2012. 14p.

JACOBY, H. (org.) A Guerra dos Tronos e a Filosofia. Rio de Janeiro: BestSeller, 2012.

KANEKO, L.; HERBELLA, R. Sociedade dos Poetas Mortos: o Ensino Jurídico no Brasil e a Morte dos Poetas. Simpósio Regional Direito e Cinema em Debate, 2.Anais. Jacarezinho,PR: UENP\&PROJURIS, 2016. p.133-49.

LACERDA, G. O direito no cinema: relato de uma experiência didática no campo do direito. Rio de Janeiro: Editora FGV, 2007.

LEYA. Literatura Fantástica: Crônicas de Gelo e Fogo. 2016. http://geral.leya.com.br/ pt/literatura-fantastica/

LIRA, A.; MOREIRA, I. 5 liçóes de empreendedorismo de Game of Thrones:saiba o que os personagens da série podem ensinar sobre o mundo dos negócios. Revista Pequenas Empresas \& Grandes Negócios. 10/04/2015.http://revistapegn.globo.com/Dia-a-dia/ noticia/2015/04/5-licoes-de-empreendedorismo-de-game-thrones.html

LOWDER, J. (org.) Além da Muralha: explorando o universo de As Crônicas de Gelo e Fogo de George R.R. Martin. São Paulo: LeYa, 2012. 240p.

MAFFEI, M. Estética medieval: Game of Thrones e os reflexos na moda. Trabalho de Conclusão de Curso. Moda. Feevale, 2014. 177p. http://biblioteca.feevale.br/Monografia/ MonografiaMarianaMaffei.pdf

MALAGÓN, R.P. O falso feminismo que 'Game of Thrones' esconde. El País.

Brasil. Opinião. 18abr.2016. http://brasil.elpais.com/brasil/2016/04/18/ cultura/1460976876_668436.html?rel=cx_articulo\#cxrecs_s

MALANOVICZ, A.V. Resenha para Ascensão e Queda de César Birotteau de Balzac e Os Pilares da Terra. 27jun.2014 e 7 fev.2016. http://recantodasletras.com.br/autor_ textos.php?pag=1 \&id=34752\&categoria $=\mathrm{K}$

MARTIN, George R.R.A Dança dos Dragóes. (A Dance with Dragons, 2011) São Paulo: LeYa, 2012b. 870p. (As Crônicas de Gelo e Fogo; 5). 
MARTIN, George R.R. A Fúria dos Reis. (A Clash of Kings, 1998) São Paulo: LeYa, 2011a. 653p. (As Crônicas de Gelo e Fogo; 2).

MARTIN, George R.R. A Guerra dos Tronos. (A Game of Thrones, 1996) São Paulo: LeYa, 2010. 592p. (As Crônicas de Gelo e Fogo; 1).

MARTIN, George R.R. A Tormenta de Espadas. (A Storm of Swords, 2000) São Paulo: LeYa, 2011b. 884p. (As Crônicas de Gelo e Fogo; 3).

MARTIN, George R.R. O Festim dos Corvos. (A Feast for Crows, 2005) São Paulo: LeYa, 2012a. 644p. (As Crônicas de Gelo e Fogo; 4).

McCAFFREY, M.; DOROBAT, C. As liçóes econômicas deGame of Thrones. Instituto Ludwig von Mises Brasil, abr.2014. http://www.mises.org.br/Article.aspx?id=1628.

MOISI, D. Por que precisamos de 'Game of Thrones'. El País. Brasil. Opinião.

21 abr.2015. http://brasil.elpais.com/brasil/2015/04/21/opinion/1429642625_615105. html

MORETTIN, E.; ROSELL, M.; FELTRIN, R.D.; RESENDE, B.T. Cinema e história noBrasil: estratégias discursivas do documentário na construção de uma memória sobre oregime militar. Projeto de Pesquisa. CNPq. 2014-2016. Recuperado em 20 jun.2019 de http://historiaeaudiovisual.weebly.com/documentaacuterios.html

MUNDO ESTRANHO: Grandes Sagas. n.159, abril, 2015. 74p.

PATI, C. As 7 melhores lições de liderança da série Game of Thrones. In: Exame. Carreira. 03maio2015. http://exame.abril.com.br/carreira/noticias/as-7-melhores-licoes-delideranca-da-serie-game-of-thrones

PINHEIRO, I.A.; VIEIRA, L.J.M. Construindo as pontes entre saberes: da Literatura à Gestão. Congresso Virtual Brasileiro, CONVIBRA, Anais... 2008. www.convibra.com. br/2008/artigos/214_0.pdf

ROLLING STONE. Game of Thrones: por dentro do maior fenômeno da televisão. Spring, São Paulo, n.3, p.54-64, jun.2014. rollingstone.com.br

ROSENBERG, A. Homens e Monstros: estupro, mitificação, ascensão e queda de naçóes em Game of Thrones. In: LOWDER, J.(org.) Além da Muralha. São Paulo: LeYa, 2012. p.22-31.

RUAS, R.L. Literatura, dramatização e formação gerencial: a apropriação de práticas teatrais ao desenvolvimento de competências gerenciais. Organizaçóes\&Sociedade, Salvador, v.12, p.121-142, 2005.

SCHULZKE, M. Jogando o Jogo dos Tronos: algumas liçôes de Maquiavel. In: JACOBY, H.(org.) A Guerra dos Tronos e a Filosofia. Rio de Janeiro: BestSeller, 2012. p.47-61. 
SOUZA, M.N.A.; MONTEIRO, A.J. O uso da tecnologia da informação e comunicação na educação superior. CONTECSI, 12., Anais... SãoPaulo, USP, 20-22maio2015. p.2667-2668. http://www.contecsi.fea.usp.br/envio/index.php/contecsi/12CONTECSI/ paper/view/2641

SPECTOR, C. Poder e Feminismo em Westeros. In: LOWDER, J.(org.) Além da Muralha. São Paulo: LeYa, 2012. p.130-143.

SUPERINTERESSANTE: Game of Thrones - O Guia Secreto: A história real e os segredos. Abril, 2015. 81p.

TAYLOR, R. Game of Thrones ensina a lidar com dinheiro; veja 5 liçôes. UOL, São Paulo. 09abr.2015. http://economia.uol.com.br/noticias/redacao/2015/04/09/game-of-thronesensina-a-lidar-com-dinheiro-veja-5-licoes.htm

TULLMAN, K. O encontro de Dany com os selvagens: relativismo cultural em A Guerra dos Tronos. In: JACOBY, H. (org.) A Guerra dos Tronos e a Filosofia. Rio de Janeiro: BestSeller, 2012. p.205-215.

UNIVERSIA. 8 liçóes de carreira de Game of Thrones. 04junho2013. http://noticias. universia.com.br/destaque/noticia/2013/06/04/1028218/8-lices-carreira-game-of-thrones. html

VAUGHT, S. O Custo Brutal da Redenção em Westeros: ou... que ambiguidade moral? In: LOWDER, J.(org.) Além da Muralha. São Paulo: LeYa, 2012. p.74-86.

VEIGA, R.; FREITAS, R.A. Efeito Autorreflexivo das Obras Cinematográficas e sua Importância para o Direito. Simpósio Regional Direito e Cinema em Debate, 4. Jacarezinho, PR: UENP\&PROJURIS, 2018. p.88-101.

WESTEROS.ORG. Westeros: the A Song of Ice and Fire domain. Website. 2019. westeros.org

WIKI of Ice and Fire. 2016. 7.053artigos. http://awoiaf.westeros.org/index.php/Main_ Page

WINSPEAR, G. AdZuna. 10 liçóes que Game of Thrones pode nos ensinar sobre a nossa carreira. 20abr.2015. www.adzuna.com.br/blog/2015/04/20/10-licoes-que-gameof-thrones-pode-nos-ensinar-sobre-a-nossa-carreira/

XAVIER, K.C.; ROSSINI, M.S. Jaime Lannister e o mito do herói em Game of Thrones. Congresso de Ciências da Comunicação na Região Sul, 16., 4-6 junho 2015, Joinville/SC. Anais... São Paulo: Intercom, 2015. 


\section{APÊNDICE - Detalhamento do Corpus Literário, Fílmico e Bibliográfico - e Outras Referências às Séries}

\begin{tabular}{|c|c|c|c|}
\hline & \multicolumn{3}{|c|}{$\begin{array}{l}\text { MARTIN, G.R.R. A Guerra dos Tronos. (A Game of Thrones. 1996) 2010. 592p. } \\
\text { MARTIN, G.R.R. A Fúria dos Reis. (A Clash of Kings. 1998) 2011a. 653p. } \\
\text { MARTIN, G.R.R. A Tormenta de Espadas. (A Storm of Swords. 2000) 2011b. 884p. } \\
\text { MARTIN, G.R.R. O Festim dos Corvos. (A Feast for Crows. 2005) 2012a. 644p. } \\
\text { MARTIN, G.R.R. A Dança dos Dragões. (A Dance with Dragons. 2011) 2012b. 870p. }\end{array}$} \\
\hline 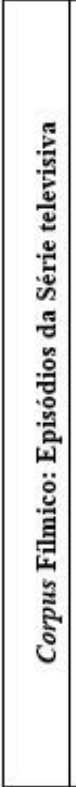 & \multicolumn{3}{|c|}{$\begin{array}{l}\text { HBO. Game ofThrones. criado e produzido por D.B.Weiss e David Benioff. Estados Unidos, HBO, } \\
\text { 2011-2019. } 73 \text { episódios (43800min./73h.) http://www.hbo.com/game-of-thrones. } \\
\text { Temporada } 1 \text { (2011): 1.1-O inverno está chegando, 1.2-A Estrada do Rei, 1.3-Lorde Snow, 1.4- } \\
\text { Aleijados, Bastardos e Coisas Partidas, 1.5-O Lobo e o Leão, 1.6-Uma Coroa Dourada, 1.7-Ganhar ou } \\
\text { Morrer, 1.8-A Ponta Afiada, 1.9-Baelor, 1.10-Fogo e Sangue. } \\
\text { Temporada } 2 \text { (2012): 2.1-O Norte se lembra, 2.2-As Terras Noturnas, 2.3-O que está morto não pode } \\
\text { morrer, 2.4-O Jardim dos Ossos, 2.5-O Fantasma de Harrenhal, 2.6-Os Deuses Antigos e os Novos, 2.7- } \\
\text { Um Homem sem Honra, 2.8-O Principe de Winterfell, 2.9-Água Negra, 2.10-Valar Morghulis. } \\
\text { Temporada } 3 \text { (2013): 3.1-Valar Dohaeris, 3.2-Asas Negras, Palavras Negras, 3.3-A Caminhada da } \\
\text { Punição, 3-4-E agora sua Patrulha Terminou, 3.5-Beijada pelo Fogo, 3.6-A Escalada, 3.7-O Urso e a Bela } \\
\text { Donzela, 3.8-Segundos Filhos, 3.9-As Chuvas de Castamere, 3.10-Mhysa. } \\
\text { Temporada } 4 \text { (2014): 4.1-Duas Espadas, 4.2-O Leão e a Rosa, 4.3-Quebradora de Correntes, 4.4- } \\
\text { Cumpridora de Promessas, 4.5-O Primeiro de Seu Nome, 4.6-As Leis dos Deuses e dos Homens, 4.7- } \\
\text { Sabiá, 4.8-A Montanha e a Vibora, 4.9-Os Patrulheiros da Muralha, 4.10-As Crianças. } \\
\text { Temporada 5 (2015): 5.1-As Guerras que Virão, 5.2-A Casa do Preto e Branco, 5.3-Alto Pardal, 5.4-Os } \\
\text { Filhos da Harpia, 5.5-Mate o Garoto, 5.6-Não Rebaixados, Não Curvados, Não Quebrados, 5.7-O } \\
\text { Presente, 5.8-Durolar, 5.9-A Dança dos Dragões, 5.10-A Misericórdia da Mãe. } \\
\text { Temporada } 6 \text { (2016): 6.1-A Mulher Vermelha, 6.2-Lar, 6.3-Quebrador de Promessas, 6.4-O Livro do } \\
\text { Estranho, 6.5-A Porta, 6.6-Sangue do Meu Sangue, 6.7-O Homem Quebrado, 6.8-Ninguém, 6.9-A } \\
\text { Batalha dos Bastardos, 6.10-Os Ventos do Inverno. } \\
\text { Temporada } 7 \text { (2017): 7.1-Pedra do Dragão, 7.2-Nascida da Tormenta, 7.3-A Justiça da Rainha, 7.4-Os } \\
\text { Despojos da Guerra, 7.5-Atalaialeste, 7.6-Além da Muralha, 7.7-O Dragão e o Lobo. } \\
\text { Temporada 8 (2019): 8.1-Winterfell, 8.2-Uma Cavaleira dos Sete Reinos, 8.3-A Longa Noite, 8.4-Os } \\
\text { Ultimos Starks, 8.5-Os Sinos, 8.6-O Trono de Ferro. }\end{array}$} \\
\hline \multirow{18}{*}{ 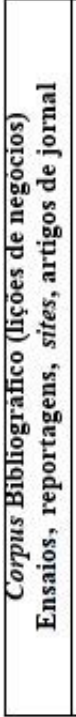 } & & Cerutti (2012) & Revista Literatura \\
\hline & Tronos & & Capit \\
\hline & As coisas que faço por a & & \\
\hline & A morte de lorde Stark: & & \\
\hline & Papel de & Hartinger (2012) & \\
\hline & 5 lições de empreendedorismo de Game of Thrones & & $\begin{array}{l}\text { Revista Pequ } \\
\& \text { Grandes N }\end{array}$ \\
\hline & O falso feminismo que 'Game of Thrones' esconde & Malagón (2016) & Artigo do Jornal E1 Pais \\
\hline & As lições econômicas de Game of Thrones & & $\begin{array}{l}\text { Website Instituto Ludwig } \\
\text { von Mises Brasil }\end{array}$ \\
\hline & 7 lições de liderança da série Game of Thrones & Pati (2015) & Revista Exame \\
\hline & Ascensão e queda de nações em Game of Thrones & & \\
\hline & Jogando o Jogo dos Tronos: lições de Maquiavel & Schulzke (2012) & Capit \\
\hline & Poder e Feminismo em Westeros & & \\
\hline & Personagens de Game of Thrones no escritório & Tay (2013) & Website Administradores \\
\hline & Game of Thrones ensina a lidar com dinheiro & & Website UOL Economia \\
\hline & Relativismo cultural em A Guerra dos Tronos & Tullman (2012) & \\
\hline & 8 lições de carreira de Game of Thrones & Universia (2013) & Website Universia \\
\hline & & & \\
\hline & 10 lições que Game of Thrones pode nos ensinar & Winspear (2015) & Blog AdZuna \\
\hline
\end{tabular}




\begin{tabular}{|c|c|c|c|}
\hline & $\begin{array}{l}\text { Game of Thrones: o impacto cultural de um } \\
\text { processo adaptativo em desenvolvimento } \\
\text { Práticas de assistir televisão: um olhar sobre a }\end{array}$ & $\begin{array}{l}\text { Abreu e } \\
\text { Indrusiak (2013) }\end{array}$ & Revista Translatio \\
\hline & série Game of Thrones na $\mathrm{HBO}$ & Cerquerra (2013) & Ciências da Comunicação \\
\hline 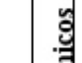 & $\begin{array}{l}\text { Game ofThrones e a Filosofia. Curso de } \\
\text { Extensão EAD }\end{array}$ & $\begin{array}{l}\text { FCE-UFRGS } \\
(2015)\end{array}$ & $\begin{array}{l}\text { Faculdade de Ciências } \\
\text { Econômicas UFRGS }\end{array}$ \\
\hline 艒 & $\begin{array}{l}\text { Curso de Extensão: Game of Thrones e a } \\
\text { Filosofia }\end{array}$ & ISAPE (2013) & $\begin{array}{l}\text { Instituto Sul-Americano de } \\
\text { Politica e Estratégia }\end{array}$ \\
\hline 영 & $\begin{array}{l}\text { Entretenimento digital na indústria cultural: } \\
\text { uma análise de conteúdo das estratégias usadas } \\
\text { na divulgação do seriado Game of Thrones }\end{array}$ & $\begin{array}{l}\text { Izídio, Cavalcanti, } \\
\text { Vilaça e Lucian } \\
\text { (2012) }\end{array}$ & $\begin{array}{l}\text { Simpósio Nacional ABCIber, } \\
\text { Entretenimento digital }\end{array}$ \\
\hline है त्ञ & $\begin{array}{l}\text { A Guerra dos Tronos e a Filosofia: a lógica } \\
\text { golpeia mais fundo que as espadas }\end{array}$ & Jacoby (2012) & $\begin{array}{l}\text { Livro A Guerra dos Tronos e a } \\
\text { Filosofia }\end{array}$ \\
\hline 며ำ & $\begin{array}{l}\text { Estética medieval: Game of Thrones e os } \\
\text { reflexos na moda }\end{array}$ & Maffei (2014) & $\begin{array}{l}\text { Trabalho de Conclusão de } \\
\text { Curso. FEEVALE }\end{array}$ \\
\hline & $\begin{array}{l}\text { Jaime Lannister e o mito do herói em Game of } \\
\text { Thrones }\end{array}$ & $\begin{array}{l}\text { Xavier e Rossini } \\
(2015)\end{array}$ & $\begin{array}{l}\text { Congresso de Ciências da } \\
\text { Comunicacão na Região Sul }\end{array}$ \\
\hline 音 & $\begin{array}{l}\text { Trono manchado de sangue: os hábitos, as } \\
\text { guerras e as figuras reais que serviram de } \\
\text { referência para As Crônicas de Gelo e Fogo }\end{array}$ & $\begin{array}{l}\text { Aventuras na } \\
\text { História (2011) }\end{array}$ & Aventuras na História \\
\hline & Por dentro da série da HBO Game of Thrones & Cogman (2013) & Editora LeYa \\
\hline 递 & $\begin{array}{l}\text { Quando se joga o Jogo dos Tronos, você vence } \\
\text { ou morre: representações sociais e disputas } \\
\text { pelo poder em Game of Thrones }\end{array}$ & $\begin{array}{l}\text { Couto e Oliveira } \\
(2015)\end{array}$ & $\begin{array}{l}\text { Revista Mediação: Mediações } \\
\text { culturais: arte, design e } \\
\text { comunicação }\end{array}$ \\
\hline & $\begin{array}{l}\text { Desafios e Enigmas dos Tronos: inspirados no } \\
\text { romance e na premiada série Game of Thrones }\end{array}$ & $\begin{array}{l}\text { Dedopulos } \\
(2015)\end{array}$ & $\begin{array}{l}\text { A Game of Thrones Puzzle } \\
\text { Quest }\end{array}$ \\
\hline & $\begin{array}{l}\text { Remix dos Cavaleiros: recirculação } \\
\text { jornalistica na forma de imagens remixadas }\end{array}$ & Dias (2014) & $\begin{array}{l}\text { Artigo de Especialização em } \\
\text { Jornalismo. Feevale }\end{array}$ \\
\hline . & Tudo sobre o universo de George R.R. Martin & $\begin{array}{l}\text { GameofThronesB } \\
\mathrm{r}(2017)\end{array}$ & Coletivo Gelo e Fogo \\
\hline 善 & $\begin{array}{l}\text { Literatura Fantástica: As Crônicas de Gelo e } \\
\text { Fogo }\end{array}$ & LeYa (2016) & Website da editora LeYa \\
\hline 泀 & $\begin{array}{l}\text { Além da Muralha: explorando o universo de } \\
\text { As Crônicas de Gelo e Fogo de George R.R. } \\
\text { Martin }\end{array}$ & Lowder (2012) & $\begin{array}{l}\text { Livro de ensaios Além da } \\
\text { Muralha }\end{array}$ \\
\hline & Por que precisamos de 'Game of Thrones" & Moisi (2015) & Jornal El País \\
\hline & MUNDO ESTRANHO: Grandes Sagas & $\begin{array}{l}\text { Mundo Estranho } \\
(2015)\end{array}$ & Revista Mundo Estranho \\
\hline & $\begin{array}{l}\text { Game of Thrones: por dentro do maior } \\
\text { fenômeno da televisão }\end{array}$ & $\begin{array}{l}\text { Rolling Stone } \\
\text { (2014) }\end{array}$ & Revista Rolling Stone \\
\hline & $\begin{array}{l}\text { SUPER INTERESSANTE: Game of Thrones } \\
\text { - O Guia Secreto (Guerra dos Tronos): A } \\
\text { história real e os segredos }\end{array}$ & $\begin{array}{l}\text { SuperInteressante } \\
(2015)\end{array}$ & Revista SuperInteressante \\
\hline & Westeros: the A Song of Ice and Fire domain & $\begin{array}{l}\text { Westeros.org } \\
(2019)\end{array}$ & Website Westeros.org \\
\hline
\end{tabular}

